\title{
1 Optimization of an LNP-mRNA vaccine candidate targeting SARS-CoV-2
}

2 receptor-binding domain

3

4 Kouji Kobiyama ${ }^{1,7}$, Masaki Imai ${ }^{2,7}$, Nao Jounai ${ }^{3,7}$, Misako Nakayama ${ }^{4,7}$, Kou Hioki ${ }^{1}$,

5 Kiyoko Iwatsuki-Horimoto ${ }^{2}$, Seiya Yamayoshi ${ }^{2}$, Jun Tsuchida ${ }^{1}$, Takako Niwa ${ }^{5}$, Takashi

6 Suzuki $^{5}$, Mutsumi Ito ${ }^{2}$, Shinya Yamada ${ }^{2}$, Tokiko Watanabe ${ }^{2}$, Maki Kiso ${ }^{2}$, Hideo

7 Negishi $^{1}$, Burcu Temizoz ${ }^{1}$, Hirohito Ishigaki ${ }^{4}$, Yoshinori Kitagawa ${ }^{6}$, Cong Thanh

8 Nguyen $^{4}$, Yasushi Itoh ${ }^{4,8}$, Fumihiko Takeshita ${ }^{3,8}$, Yoshihiro Kawaoka ${ }^{2,8}$, and Ken J.

$9 \quad$ Ishii $^{1,8}$

10

$11{ }^{1}$ Division of Vaccine Science,

$12{ }^{2}$ Division of Virology, Department of Microbiology and Immunology, The Institute of

13 Medical Science, The University of Tokyo, 4-6-1 Shirokanedai, Minato-ku, Tokyo

14 108-8639, Japan.

$15{ }^{3}$ Biologics Division, Vaccine Research Laboratories, Daichi Sankyo Co., Ltd. 1-16-13,

16 Kitakasai, Edogawa-ku, Tokyo 134-0081, Japan

$17{ }^{4}$ Division of Pathogenesis and Disease Regulation, Department of Pathology, Shiga

18 University of Medical Science, Setatsukinowa, Otsu, Shiga 520-2192, Japan

$19{ }^{5}$ Biologics Division, Modality Research Laboratories, Daichi Sankyo Co., Ltd. 1-2-58,

20 Hiromachi, Shinagawa-ku, Tokyo 134-0081, Japan

$21{ }^{6}$ Division of Microbiology and Infectious Diseases, Department of Pathology, Shiga

22 University of Medical Science, Setatsukinowa, Otsu, Shiga 520-2192, Japan

$24{ }^{7}$ The authors are contributed to this work equally

$26 \quad{ }^{8}$ Correspondence should be addressed to

27 Ken J. Ishii kenishii@ims.u-tokyo.ac.jp, or

28 Yoshihiro Kawaoka kawaoka@ims.u-tokyo.ac.jp

29 Fumihiko Takeshita takeshita.fumihiko.aw@daiichisankyo.co.jp

30 Yasushi Itoh yasushii@belle.shiga-med.ac.jp 
In 2020, two mRNA-based vaccines, encoding the full length of severe acute respiratory syndrome coronavirus 2 (SARS-CoV-2) spike protein, have been introduced for control of the coronavirus disease (COVID-19) pandemic ${ }^{1,2}$. However, reactogenicity, such as fever, caused by innate immune responses to the vaccine formulation remains to be improved. Here, we optimized a lipid nanoparticle (LNP)-based mRNA vaccine candidate, encoding the SARS-CoV-2 spike protein receptor-binding domain (LNP-mRNA-RBD), which showed improved immunogenicity by removing reactogenic materials from the vaccine formulation and protective potential against SARS-CoV-2 infection in cynomolgus macaques. LNP-mRNA-RBD induced robust antigen-specific B cells and follicular helper $T$ cells in the BALB/c strain but not in the $\mathrm{C57BL} / 6$ strain; the two strains have contrasting abilities to induce type I interferon production by dendritic cells. Removal of reactogenic materials from original synthesized mRNA by HPLC reduced type I interferon (IFN) production by dendritic cells, which improved immunogenicity. Immunization of cynomolgus macaques with an LNP encapsulating HPLC-purified mRNA induced robust anti-RBD IgG in the plasma and in various mucosal areas, including airways, thereby conferring protection against SARS-CoV-2 infection. Therefore, fine-tuning the balance between the immunogenic and reactogenic activity of mRNA-based vaccine formulations may offer safer and more efficacious outcomes.

The SARS-CoV-2 spike glycoprotein contains a receptor-binding domain (RBD) that binds to human angiotensin-converting enzyme 2 (hACE2) as a receptor to facilitate membrane fusion and cell entry ${ }^{3}$. Recent evidence suggests that the immune response to the SARS-CoV-2 spike protein is the key to controlling SARS-CoV-2 infection; a vaccine that can induce robust and specific $\mathrm{T}$ and $\mathrm{B}$ cells against the receptor-binding domain (RBD) of the spike protein antigen of SARS-CoV-2 may be ideal for protective efficacy and safety ${ }^{4}$. Accordingly, various animal experiments have demonstrated that the induction of humoral and cellular immune responses to the RBD by various types of vaccines confers protective efficacy with no signs of detrimental outcomes such as antibody-dependent enhancement ${ }^{5,6}$.

Concurrently with animal studies, a number of human clinical trials with various types of vaccines against COVID-19 have been initiated, conducted, and completed globally within a year after the viral genome sequence was reported in 
66 Wuhan, China, in December 20197 . Two mRNA vaccines encoding the full-length spike 67 protein of SARS-CoV-2 have undergone Phase I-II-III trials, which were completed in nine months and approved by regulatory authorities in various countries as well as the $\mathrm{WHO}^{1,2,8-10}$. The results of their initial phase I-II clinical trials suggest that in both younger and older adults, the two vaccine candidates elicited similar dose-dependent SARS-CoV-2-neutralizing geometric mean titers, which were equivalent to that of a panel of SARS-CoV-2 convalescent serum samples ${ }^{9,10}$. It is worth noting that an mRNA vaccine (BNT162b2) encoding the full length of the SARS-CoV-2 spike protein was associated with a lower incidence and severity of systemic reactions than another mRNA vaccine encoding the RBD of spike protein (BNT162b1), particularly in older adults $^{10}$. A few scientific explanations have been offered: one is the amount of mRNA in the RBD-mRNA vaccine, whose molar ratio is five times more than that of the full-length mRNA vaccine due to an RNA length shorter by $1 / 5$ at the same dose. Although each RNA modification in the in vitro translated (IVT) mRNA to avoid innate immune recognition was made, the number or position of the modified nucleoside of the mRNAs may alter their immunostimulatory activity, acting as an endogenous adjuvant. Here, we optimized an mRNA vaccine candidate encoding SARS-CoV-2 spike protein RBD (319-541 aa) encapsulated in lipid nanoparticles (LNP-mRNA-RBD).

To date, a mouse model using the BALB/c strain has been commonly used $^{6,11,12}$, except for one study where C57BL/6 mice were immunized with LNP-mRNA encoding SARS-CoV-2 RBD, resulting in antigen-specific germinal center (GC) B cells and follicular helper $\mathrm{CD}^{+} \mathrm{T}$ cells $\left(\mathrm{T}_{\mathrm{FH}}\right)$ cells $^{13}$.

First, we immunized 6-8-week-old female mice of either the C57BL/6 or $\mathrm{BALB} / \mathrm{c}$ strains intramuscularly with $3 \mu \mathrm{g}$ of LNP-mRNA-RBD on days 0 and 14 . Unexpectedly, after two intramuscular immunizations, LNP-mRNA-RBD induced significantly higher anti-RBD antibody responses in BALB/c mice but not in C57BL/6 mice in this study (Fig. 1a, Extended Fig 1). To understand why LNP-mRNA-RBD

93 immunogenicity for antigen-specific B cell responses was different among mouse 94 strains, we further examined whether LNP-mRNA-RBD induces $\mathrm{T}_{\mathrm{FH}}$ and GC B cells 95 collected from the draining popliteal lymph nodes $(\mathrm{pLN})$ and analyzed by flow 96 cytometry (Extended data Fig. 2). In correlation with serum antibody responses, the 97 frequency $(\%)$ of both $\mathrm{T}_{\mathrm{FH}}\left(\mathrm{CD} 4^{+} \mathrm{CD} 185^{+} \mathrm{PD}-1^{+}\right.$cells $)$and $\mathrm{GC} \mathrm{B}$ cells $98\left(\mathrm{CD}^{-} 8^{-} \mathrm{GL}^{+} \mathrm{CD} 19^{+}\right.$cells) in the immunized $\mathrm{pLN}$ was significantly higher in BALB/c 
mice than that in C57BL/6 mice (Fig. 1b-e) after LNP-mRNA-RBD immunization.

To further evaluate antigen-specific $\mathrm{CD} 8^{+}$and other $\mathrm{CD} 4^{+} \mathrm{T}$ cells induced by

101 LNP-mRNA-RBD, we synthesized 128 peptides, consisting of a 20 -aa sequence of

102 spike protein with 10 overlapping aa divided into eight pools containing 16 peptides in

103 one pool (Fig. 1f). After two LNP-mRNA-RBD immunizations in either mouse strain,

104 in vitro re-stimulation of the immunized spleen with peptide pools 3 and 4 induced

105 substantial IFN- $\gamma$ production in $\mathrm{C} 57 \mathrm{BL} / 6$ mice, while in BALB/c mice this was

106 achieved with peptide pool 3 (Fig. 1g and h, Extended data Fig. 3a and b). IL-13

107 production was not found in the supernatant of the spleen cell culture with peptides in

108 either C57BL/6 or BALB/c mice (Extended data Fig. 3c and d). To further

109 characterize LNP-mRNA-RBD-induced T cells, we performed intracellular cytokine

110 staining of three antigen-specific type-1 cytokines (IL-2, IFN- $\gamma$, and TNF- $\alpha$ ) produced

111 by the immunized spleen T cells re-stimulated with peptide pools 2, 3, or 4 . Spike

112 antigen-specific polyfunctional $\mathrm{CD} 8^{+}$and $\mathrm{CD} 4^{+} \mathrm{T}$ cells were significantly upregulated

113 in LNP-mRNA-RBD-immunized BALB/c mice after re-stimulating the spleen cells

114 with peptide pools 3 and 4 (Fig. 1h, Extended data Fig. 4b and 5b). However, those in

115 the immunized C57BL/6 mice showed substantial polyfunctional CD8 ${ }^{+} \mathrm{T}$ cells and

116 weak $\mathrm{CD}^{+} \mathrm{T}$ cell responses (Fig. 1g, Extended data Fig. 4a and 5a). These data

117 clearly demonstrate that LNP-mRNA-RBD induces robust B and T cell responses in

$118 \mathrm{BALB} / \mathrm{c}$ mice but relatively weak $\mathrm{T}$ cell and $\mathrm{B}$ cell responses in $\mathrm{C} 57 \mathrm{BL} / 6$ mice,

119 suggesting the immunogenic profile of LNP-mRNA-RBD is different between these

120 mouse strains.

121 Nucleic acid-based vaccines are known to utilize their backbone DNA or

122 RNA as built-in adjuvants ${ }^{14-16}$. In LNP-mRNA vaccines, it has been shown that mRNA

123 itself acts as an endogenous adjuvant sensed by Toll-like receptors 3, 7, or 8 and/or

124 cytosolic RNA sensors such as RIG-I and MDA5 ${ }^{17}$. Kariko et al. reported that

125 modification of RNA by methylation or incorporating modified nucleoside such as

126 pseudouridine enables the escape from innate immune sensing, thereby improving

127 translation efficiency ${ }^{18,19}$. Several studies have revealed that type I IFN interferes with

128 the CD8 T cell responses elicited by LNP-mRNA and the translation efficiency of the

129 encoded protein ${ }^{20,21,22}$. In addition to T cell responses, BNT162b1 showed higher

130 reactogenicity than BNT162b2 in the clinical trial; therefore, BNT162b2 has been

131 selected for further development in a Phase III clinical trial ${ }^{10}$. The reason for the 
132 difference in reactogenicity remains unclear, but the authors considered that

133 immunostimulatory activity of the mRNA in LNP formulation might be attributed to its

134 reactogenicity $^{10}$.

135 In order to translate our findings from mice to humans, we then examined

136 whether LNP-mRNA-RBD triggers type I IFN production from human PBMCs. When

137 mixed with LNP-mRNA-RBD in vitro, PBMCs from three healthy humans produced a

138 higher amount of IFN- $\alpha$ than that induced by LNP-mRNA-Full (Fig. 2a). We then

139 performed a similar experiment using mouse bone marrow-derived dendritic cells

140 (BM-DCs) from either C57BL/6 or BALB/c mice. Surprisingly, a high level of IFN- $\alpha$

141 was observed upon culture with LNP-mRNA-full or LNP-mRNA-RBD in C57BL/6

142 mice, but very low or no IFN- $\alpha$ production was observed in BALB/c mice (Fig. 2 b).

143 LNP-mRNA products usually contain undesirable RNA, such as dsRNA as TLR3

144 ligand $^{22}$, produced during the manufacturing process, which might affect innate immune

145 activation. To remove such RNA byproducts, we performed HPLC purification (data

146 not shown) and then the resultant mRNA containing the active ingredient was

147 encapsulated in LNP [RBD (HPLC)]. RBD (HPLC) showed significantly less potential

148 in production of type I IFN from both human PBMCs and GM-DCs (Fig. 2a and b). In

149 order to examine the immunogenicity, C57BL/6 or BALB/c mice were administered

150 with RBD (HPLC) or LNP-mRNA-RBD. Of interest, RBD (HPLC) showed

151 significantly higher levels of the RBD-specific B cell response than LNP-mRNA-RBD,

152 including serum IgG1, IgG2, and total $\mathrm{IgG}$ in both BALB/c and C57BL/6 mice (Fig. 2c

153 and Extended Fig. 6a). In particular, RBD (HPLC) induced significantly higher

154 number of GC B cells in the draining lymph nodes of the C57BL/6 mice than

155 LNP-mRNA-RBD (Fig. 2d and e). In addition to antibody responses, effects of

156 RNA-purification on antigen-specific $\mathrm{T}$ cell responses were further examined. RBD

157 (HPLC) induced higher frequency of the RBD-specific polyfunctional CD8 ${ }^{+}$and $\mathrm{CD} 4^{+}$

158 T cells that produced significantly more IFN- $\gamma$ and other type- 1 cytokines, but not

159 type-2 cytokines such as IL-13, in response to peptide pools 3 or 4 re-stimulation than

160 LNP-mRNA-RBD (Fig. 2f-i, and Extended Fig. 6b-e, 7, 8).

161 To further translate these findings to a more relevant pre-clinical evaluation of

162 RBD (HPLC), non-human primates (NHPs), cynomolgus macaques, were chosen for

163 further study. In this study, we immunized four macaques intramuscularly with RBD

164 (HPLC) with two macaques as mock controls. After the first immunization, RBD 
165 (HPLC) induced an anti-RBD-specific antibody, and the second immunization enhanced 166 these responses (Fig. 3b). Neutralizing antibodies were also induced by RBD (HPLC) 167 vaccination (Fig. 3c). We further examined antigen-specific antibody responses in swab 168 samples. Interestingly, following intramuscular immunization, levels of RBD-specific 169 IgG in the swab samples from conjunctiva, nasal cavity, oral cavity, trachea, and rectum 170 were significantly higher in RBD (HPLC) group than in the mock group (Fig. 3d). Individual macaques administered with RBD (HPLC) showed drastically 172 lower RNA levels of SARS-CoV-2 (Fig. 4a) and infectious virus (Fig. 4b) in the swab 173 at day 1 post-infection than those administered with mock. Viral RNA levels in the 174 trachea, bronchus, and lung were lower in vaccinated macaques at day 7 (Fig. 4c and

175 Extended Fig. 9). All mock-administered macaques manifested fever and pneumonia 176 after viral infection, which were not observed in immunized macaques (Extended Fig.

17710 and 11). These results suggest that RBD (HPLC) administration confers protection against SARS-CoV-2 infection. Histological analysis of the lung at 7 days post infection demonstrated infiltration of lymphocytes and neutrophils, alveolar wall

180 thickening, and viral protein in macaques administered with mock but not in those 181 administered with RBD (HPLC) (Fig. 4d and 4e). Accordingly, histological scores of 182 the lung in macaques administered with RBD (HPLC) were lower than those

183 administered with mock (Fig. 4f). Of importance, intramuscular administration with 184 RBD (HPLC) induced the development of bronchus-associated lymphoid tissue (BALT) 185 (Fig. 4d), although intramuscular immunization induced RBD-specific IgG, but not IgA, 186 in swab samples without intranasal and intratracheal virus challenge (Fig. 3b).

187 Interestingly, the IgG titer was slightly reduced or similar after viral challenge (Fig. 3d). 188 These results suggest that the induced antibody in the mucosa through BALT formation, 189 such as the nasal and trachea mucosa, might capture and neutralize SARS-CoV-2, 190 resulting in the reduction of viral RNA and infective virus in the swab at day 1 191 post-challenge.

192 In this study, we evaluated the nonclinical efficacy of LNP-mRNA vaccine 193 candidates targeting SARS-CoV-2 RBD. First, LNP-mRNA-RBD showed higher 194 immunogenicity only in BALB/c mice than in C57BL/6 mice (Fig. 1a). We initially 195 interpreted the data by suggesting the less T cell epitopes of the RBD in C57/BL6 as the 196 cause. In fact, CD4 Tfh induction was lower in C57BL/6 mice than that of BALB/c 197 mice even after HPLC purification (Fig.1e and 2e). However, recent clinical trials by 
198 BioNTech/Pfizer showed that an mRNA vaccine that encoded the RBD resulted in a

199 high titer of RBD-specific IgG and neutralizing antibodies in humans and monkeys.

200 These results suggest that RBD does contain T cell epitopes, at least in primates ${ }^{6,10}$.

201 These data led us to hypothesize that the difference in vaccine-induced adaptive

202 immune responses is altered by the species- or strain-specific innate immune responses

203 to the LNP-mRNA formulation, which is shown to interfere with the mRNA expression

204 of the protein antigen of interest, thereby reducing immunogenicity and efficacy ${ }^{16}$. Our

205 data strongly suggest that optimization of purification and formulation of LNP-mRNA

206 contributes to improvement of LNP-mRNA immunogenicity with less reactogenicity.

It is of note that macaques administered with LNP-mRNA targeting RBD acquired significantly high levels of protective IgG specific to SARS-CoV-2 in mucosal swab samples from conjunctiva, oral cavity, nasal cavity, trachea, bronchus, and rectum

210 (Fig. 3d and data not shown). Corbett KS et al. recently demonstrated that vaccination

211 of NHPs with LNP-mRNA encoding the full-length spike antigen (mRNA-1273)

212 induced robust SARS-CoV-2 neutralizing activity and rapid protection in the upper and

213 lower airways and showed that the IgG level in the BALF was higher than the IgA level

214 after the infection, although whether the vaccine antigen-specific IgG was induced

215 before the virus challenge was not shown ${ }^{23}$. Although HPLC-purified

216 LNP-mRNA-RBD elicited RBD-specific mucosal IgG, no RBD-specific IgA was

217 detected (data not shown), indicating that the mucosal IgG through BALT formation or

218 leaked from the blood circulation, which may be critical for the protective efficacy of

219 LNP-mRNA-RBD. Further detailed analyses are needed to clarify whether LNP-mRNA

220 induces unique and/or specific immune responses including IgG secretion in the mucosa

221 after intramuscular vaccination.

222 Based on our results obtained in murine and NHP models, reduction of

223 reactogenicity without losing immunogenicity, in other words, fine-tuning of the

224 balance between endogenous adjuvant activity and antigen translation efficiency of

225 LNP-mRNA, may provide a means towards better efficacy and safety and will also be

226 crucial for the development of anti-SARS-CoV2 vaccines in the near future. 
228 Figure legends

229 Figure 1. Mouse strain-specific immunogenicity of mRNA vaccine against

230 SARS-CoV-2 RBD.

231 (a-e, g, and h) Six to eight week-old C57BL/6 and BALB/c mice were

232 intramuscularly immunized with mock or LNP-mRNA-RBD $(3 \mu \mathrm{g})$ at days 0 and 14.

233 (a) Two weeks after the second immunization, plasma anti-RBD antibody titers were 234 measured using ELISA. (b-e) Popliteal lymph nodes were collected from immunized

235 mice. (b-d) GC B cells were gated as $\mathrm{GL} 7^{+} \mathrm{CD} 38^{-} \mathrm{CD} 19^{+}$cells. (e) $\mathrm{T}_{\mathrm{FH}}$ cells were gated 236 as $\mathrm{CD} 185^{+} \mathrm{PD}-1^{+} \mathrm{CD} 3 \varepsilon^{+} \mathrm{CD} 4^{+} \mathrm{T}$ cells. (f) Overlapping peptides of SARS-CoV-2 spike

237 protein. Overlapping peptides were divided into eight pools, and each pool contained 16

238 peptides. (g-h) Cells were harvested from the spleen of mRNA-RBD immunized mice

239 and re-stimulated with pooled peptides for $24 \mathrm{~h}$. IFN- $\gamma$ levels in the culture supernatant

240 were measured using ELISA. (g-h) Percentages of cytokine-producing CD $8^{+}$and CD $4^{+}$

241 T cells after stimulation with pools 2,3 , and 4 for $6 \mathrm{~h}$ with protein transport inhibitor are

242 shown in a pie chart. $3^{+}:$IFN- $\gamma^{+} \mathrm{IL}-2^{+} \mathrm{TNF}-\alpha^{+}, 2^{+}:$IFN- $\gamma^{+} \mathrm{IL}-2^{+}, \mathrm{IFN}-\gamma^{+} \mathrm{TNF}-\alpha^{+}$, and

$243 \mathrm{IL}-2^{+} \mathrm{TNF}-\alpha^{+}, 1^{+}: \mathrm{IFN}-\gamma^{+}, \mathrm{IL}-2^{+}$, and TNF- $\alpha^{+} . N=4-5$ mice per group, mean $\pm \mathrm{SEM}, * p$

$244<0.05$ by Mann-Whitney test.

245

246 Figure 2. HPLC purification improves the immunogenicity of mRNA vaccine. (a)

247 Human PBMCs from non-infected individuals were stimulated with LNP-mRNA-Full

$248(0.4,2$, and $10 \mu \mathrm{g} / \mathrm{mL}), \mathrm{LNP}-\mathrm{mRNA}-\mathrm{RBD}(0.4,2$, and $10 \mu \mathrm{g} / \mathrm{mL})$, or

249 LNP-mRNA-RBD (HPLC) $(0.4,2$, and $10 \mu \mathrm{g} / \mathrm{mL})$ for $24 \mathrm{~h}$. IFN- $\alpha$ level in the culture

250 supernatant was measured using ELISA. (b) Bone-marrow-derived dendritic cells

251 (BM-DCs) from C57BL/6 and BALB/c mice were stimulated by LNP-mRNA-Full (0.4,

252 2, and $10 \mu \mathrm{g} / \mathrm{mL})$, LNP-mRNA-RBD $(0.4,2$, and $10 \mu \mathrm{g} / \mathrm{mL})$, or LNP-mRNA-RBD

253 (HPLC) $(0.4,2$, and $10 \mu \mathrm{g} / \mathrm{mL})$ for $24 \mathrm{~h}$. IFN- $\alpha$ level in the culture supernatant was

254 measured using ELISA. (c-i) C57BL/6 mice were intramuscularly immunized with

255 mock, LNP-mRNA-RBD (3 $\mu \mathrm{g})$, or LNP-mRNA-RBD (HPLC) (3 $\mu \mathrm{g})$ at days 0 and 14.

256 (c) Two weeks after the second immunization, plasma anti-RBD antibody titers were

257 measured using ELISA. (d and e) Popliteal lymph nodes were collected from

258 immunized mice. (d) GC B cells were gated as $\mathrm{GL}^{+} \mathrm{CD} 38^{-} \mathrm{CD} 19^{+}$cells. (e) $\mathrm{T}_{\mathrm{FH}}$ cells

259 were gated as $\mathrm{CD} 185^{+} \mathrm{PD}-1^{+} \mathrm{CD} 3 \varepsilon^{+} \mathrm{CD} 4^{+} \mathrm{T}$ cells. (f and $\mathbf{g}$ ) Cells were harvested from

260 the spleen of immunized mice and re-stimulated with pooled peptides for $24 \mathrm{~h}$. IFN- $\gamma$ 
261 level in the culture supernatant was measured using ELISA. Percentages of

262 cytokine-producing $\mathrm{CD}^{+}$and $\mathrm{CD}^{+} \mathrm{T}$ cells after stimulation of peptide pools 3 and 4

263 for $6 \mathrm{~h}$ with protein transport inhibitors are shown in a pie chart. $3^{+}$: IFN- $\gamma^{+} \mathrm{IL}-2^{+} \mathrm{TNF}-\alpha^{+}$,

$264 \quad 2^{+}:$IFN- $\gamma^{+} \mathrm{IL}_{-2}{ }^{+}, \mathrm{IFN}-\gamma^{+} \mathrm{TNF}-\alpha^{+}$, and IL-2 ${ }^{+} \mathrm{TNF}-\alpha^{+}, 1^{+}: \mathrm{IFN}-\gamma^{+}, \mathrm{IL}-2^{+}$, and TNF- $\alpha^{+} .(\mathbf{h}$

265 and i) Representative data from Figure 2f, g, Extended data Fig. 8, and 9 are shown.

266 IFN $-\gamma^{+} \mathrm{IL}-2^{+} \mathrm{TNF}-\alpha^{+}$and IFN $-\gamma^{+} \mathrm{TNF}-\alpha^{+} \mathrm{CD} 8^{+} \mathrm{T}$ cell are shown as a scatter dot plot. $N=$

$2674-5$ mice per group, mean \pm SEM, $* p<0.05$ by ANOVA followed by Dunn's multiple

268 comparisons test.

269

270

Figure 3. HPLC-purified LNP-mRNA-RBD induces RBD-specific antibodies in the plasma and swab samples of non-human primates (a) Schedule of immunization, infection, and sample collection. (b-c) Cynomolgus macaques were intramuscularly immunized with mock or LNP-mRNA-RBD (HPLC) $(100 \mu \mathrm{g})$ at days 0 and 21. (b)

274 Plasma anti-RBD antibody titer at days 0, 7, 14, 21, 28, and 7 dpi were measured using ELISA. (c) Neutralizing activity against SARS-CoV-2 infection were measured by neutralization assay. (d) Anti-RBD IgG titers in the swab samples (conjunctiva, oral cavity, nasal cavity, tracheal, and rectum) were measured using ELISA. Black arrows indicate date of vaccination, and red arrows indicate infection date.

SARS-CoV-2 $\left(2 \times 10^{7} \mathrm{PFU}\right)$ was inoculated into conjunctiva, nasal cavity, oral cavity, and trachea of cynomolgus. (a) Viral RNA and (b) viral titers in the swab sample were measured by RT-PCR and a cell culture method. (c) Viral RNA in the lung tissues were measured by RT-PCR. RU: right upper lobe, RM: right middle lobe, RL: right lower lobe, LU: left upper lobe, LM: left middle lobe, LL: left lower lobe. (d) HE staining and (e) immunohistochemical staining of viral nucleocapsid protein in lung sections from Mock (left) and mRNA-RBD (HPLC) (right) immunized macaques. (f) The average histological scores of eight sections in each macaque were evaluated in a blinded manner. 
294 Extended data Fig 1. LNP-mRNA-RBD vaccine induces ectodomain-specific

295 antibody responses in BALB/c mice. $\mathrm{C} 57 \mathrm{BL} / 6$ and $\mathrm{BALB} / \mathrm{c}$ mice were

296 intramuscularly immunized with mock or LNP-mRNA-RBD $(3 \mu \mathrm{g})$ on days 0 and 14.

297 Two weeks after the second immunization, plasma anti-ECD antibody titers were

298 measured using ELISA. $N=4-5$ mice per group, mean \pm SEM, $* p<0.05$ by

299 Mann-Whitney test.

300

301 Extended data Fig 2. Gating strategy for GC B and $\mathbf{T}_{\mathbf{F H}}$ cells. Cells were harvested

302 from popliteal lymph nodes of immunized mice and stained for GC B and $\mathrm{T}_{\mathrm{FH}}$ cells.

303 Cells were gated for lymphocyte size, singlets, live, T or B cells, and $\mathrm{T}_{\mathrm{FH}}$ or GC B cells.

304

305 Extended data Fig 3. T cell responses to LNP-mRNA-RBD. Cells were harvested 306 from the spleen of mRNA-immunized mice, re-stimulated by the spike protein peptide 307 pool, ECD, or RBD for $24 \mathrm{~h}$. IFN- $\gamma$ and IL-13 levels in the culture supernatant were 308 measured using ELISA. $N=4-5$ mice per group, mean \pm SEM, $* p<0.05$ by ANOVA 309 followed by Sidak's multiple comparisons test.

311 Extended data Fig 4. CD8 T cell responses to the mRNA vaccine. Cells were

312 harvested from the spleen of immunized mice and re-stimulated by pooled peptides for $3136 \mathrm{~h}$ with a protein transport inhibitor. The percentage of cytokine-producing $\mathrm{CD} 8^{+} \mathrm{T}$

314 cells was analyzed by flow cytometry. $N=4-5$ mice per group, mean $\pm \mathrm{SEM},{ }^{*} p<0.05$ 315 by Mann-Whitney test.

317 Extended data Fig 5. CD4 T cell responses to the mRNA vaccine. Cells were

318 harvested from the spleen of immunized mice and re-stimulated by pooled peptides for $3196 \mathrm{~h}$ with a protein transport inhibitor. Percentage of cytokine-producing $\mathrm{CD}^{+} \mathrm{T}$ cells 320 was analyzed by flow cytometry. $N=4-5$ mice per group, mean $\pm \mathrm{SEM},{ }^{*} p<0.05$ by 321 Mann-Whitney test.

323 Extended data Fig 6. $\mathbf{T}$ cell responses to an HPLC-purified mRNA vaccine in 324 C57/BL6 mice. (a) C57/BL6 and BALB/c mice were intramuscularly immunized with 325 mock, mRNA-RBD, or RBD (HPLC) ( $3 \mu \mathrm{g})$ on days 0 and 14 . Two weeks after the 326 second immunization, serum anti-ECD antibody titers were measured using ELISA. (b- 
327 e) Cells were harvested from the spleen of mRNA-immunized mice, re-stimulated by

328 the peptide pool of spike protein, ECD, or RBD for $24 \mathrm{~h}$. IFN- $\gamma$ and IL-13 levels in the 329 culture supernatant were measured using ELISA. $N=4$ mice per group, mean $\pm \mathrm{SEM}$, *

$330 p<0.05$ by ANOVA followed by Dunn's or Sidak's multiple comparisons test.

332 Extended data Fig 7. T cell responses to an HPLC-purified mRNA vaccine in

333 C57/BL6 mice. Cells were harvested from the spleen of immunized mice and

334 re-stimulated by pooled peptides for $6 \mathrm{~h}$ with a protein transport inhibitor. The

335 percentage of cytokine-producing $\mathrm{CD} 8^{+}$and $\mathrm{CD}^{+} \mathrm{T}$ cells was analyzed by flow

336 cytometry. $N=4$ mice per group, mean \pm SEM, ${ }^{*} p<0.05$ by ANOVA followed by

337 Dunn's multiple comparisons test.

339 Extended data Fig 8. T cell responses to an HPLC-purified mRNA vaccine in

340 BALB/c mice. Cells were harvested from the spleen of immunized mice and

341 re-stimulated with pooled peptides for $6 \mathrm{~h}$ with a protein transport inhibitor. The

342 percentage of cytokine-producing $\mathrm{CD} 8^{+}$and $\mathrm{CD} 4^{+} \mathrm{T}$ cells was analyzed by flow

343 cytometry. $N=4$ mice per group, mean \pm SEM, $* p<0.05$ by ANOVA followed by

344 Dunn's multiple comparisons test.

346 Extended data Fig 9. HPLC-purified mRNA vaccine protects against SARS-CoV-2

347 infection in non-human primates. One week after the second immunization,

348 SARS-CoV-2 $\left(2 \times 10^{7} \mathrm{PFU}\right)$ was inoculated into conjunctiva, nasal cavity, oral cavity,

349 and trachea of cynomolgus. Viral RNA in the trachea and bronchus tissues were

350 measured by RT-PCR.

352 Extended data Fig 10. Change in body temperature after SARS-CoV-2 infection

353 One week after the second immunization, SARS-CoV-2 $\left(2 \times 10^{7} \mathrm{PFU}\right)$ was inoculated

354 into conjunctiva, nasal cavity, oral cavity, and trachea of cynomolgus. Body temperature

355 was recorded from two days before infection using telemetry transmitters and a

356 computer.

358 Extended data Fig 11. The HPLC-purified mRNA vaccine protects against

359 SARS-CoV-2-induced pneumonia. X-ray radiographs of macaques were taken before 
bioRxiv preprint doi: https://doi.org/10.1101/2021.03.04.433852; this version posted March 4, 2021. The copyright holder for this preprint (which was not certified by peer review) is the author/funder, who has granted bioRxiv a license to display the preprint in perpetuity. It is made available under aCC-BY-NC-ND 4.0 International license.

360 and after SARS-CoV-2 infection.

361

362 


\section{Mice}

366 Six to eight week-old C57BL/6 and BALB/c mice were purchased from CLEA, Japan.

367 The mice were maintained under specific pathogen-free conditions. All mouse studies

368 were approved by the Animal Experiment Committee of the Institute of Medical

369 Science, University of Tokyo.

370

\section{Cynomolgus macaque}

372 Seven to ten-year-old female cynomolgus macaques born at Shiga University of

373 Medical Science and originating from Philippines, Vietnam, and China were used. All procedures were performed under ketamine and xylazine anesthesia, and all efforts were made to minimize suffering. Food pellets of CMK-2 (CLEA Japan, Inc., Tokyo, Japan) were provided once a day after recovery from anesthesia and drinking water was available ad libitum. The animals were singly housed in cages under controlled conditions of light (12-h light/12-h dark cycle, lights on at 8:00 a.m.). The macaques were challenged with the SARS-CoV-2 $\left(2 \times 10^{7} \mathrm{PFU} / 7 \mathrm{~mL}\right.$ HBSS $)$, which was inoculated into the conjunctiva $(0.05 \mathrm{~mL} \times 2)$, nostrils $(0.5 \mathrm{~mL} \times 2)$, oral cavity $(0.9$ $\mathrm{mL})$, and trachea $(5 \mathrm{~mL})$ with pipettes and catheters under ketamine/xylazine anesthesia.

382 Under ketamine/xylazine anesthesia, two cotton sticks (Eiken Chemical, Ltd., Tokyo,

383 Japan) were used to collect fluid samples from the conjunctivas, nasal cavities, oral cavities and tracheas, and the sticks were subsequently immersed in $1 \mathrm{~mL}$ of Dulbecco's modified Eagle medium (DMEM, Nacalai Tesque, Kyoto, Japan) containing 0.1\% bovine serum albumin (BSA) and antibiotics. A bronchoscope (MEV-2560; Machida Endoscope Co. Ltd., Tokyo, Japan) and cytology brushes (BC-203D-2006; Olympus

388 Co., Tokyo, Japan) were used to obtain bronchial samples.

\section{LNP-mRNA vaccines}

391 T7 RNA polymerase-mediated transcription in vitro was used to synthesize the mRNA

392 from a linearized DNA template, which flanked the open-reading frames of RBD with 393 the 5' and 3' untranslated regions and a poly-A tail. Messenger RNA for RBD (HPLC)

394 was purified by reversed phase chromatography. Messenger RNA was encapsulated into 395 lipid nanoparticles (LNP) composed of ionizable lipid, phospholipid, cholesterol, and 
396 PEG-lipid.

397

\section{Reagents}

399 Overlapping 20-aa peptides of spike protein were synthesized and purchased from

400 Eurofins Genomics (Ebersberg, Germany). The SARS-CoV-2 spike protein (ECD) and 401 RBD were purchased from GenScript (Piscataway, NJ, USA).

402

403 Virus

404 SARS-CoV-2 isolates were propagated in VeroE6 cells in Opti-MEM I (Invitrogen,

405 Carlsbad, CA, USA) containing $0.3 \%$ bovine serum albumin (BSA) and $1 \mu \mathrm{g}$ of

406 L-1-tosylamide-2-phenylethyl chloromethyl ketone (TPCK)-treated trypsin $/ \mathrm{mL}$ at $37^{\circ} \mathrm{C}$.

407

\section{Immunization}

409 Six to eight week-old C57BL/6 and BALB/c mice were intramuscularly immunized with mock, LNP-mRNA-RBD (3 $\mu \mathrm{g})$, or LNP-mRNA-RBD (HPLC) $(3 \mu \mathrm{g})$ on days 0 and 14. Two weeks after the second immunization, the popliteal lymph nodes, spleen, and blood were collected. Cynomolgus macaques were intramuscularly immunized with mock or LNP-mRNA-RBD (HPLC) $(100 \mu \mathrm{g})$ on days 0 and 21. Blood was drawn on

414 days $0,7,14,21$, and 28 .

\section{ELISA}

417 ECD and RBD-specific antibody titers were measured using ELISA. In brief, half-area

418 96-well plates were coated with ECD $(1 \mu \mathrm{g} / \mathrm{mL})$ or RBD $(1 \mu \mathrm{g} / \mathrm{mL})$ in bicarbonate

419 buffer at $4^{\circ} \mathrm{C}$. Plates were blocked with PBS containing 1\% BSA for 60 min at room

420 temperature. Plates were washed with PBST three times and incubated with diluted

421 plasma or swab samples at room temperature for $120 \mathrm{~min}$. Plates were washed with

422 PBST three times and incubated with HRP-labeled goat anti-mouse IgG, IgG1, IgG2a,

$423 \mathrm{IgG} 2 \mathrm{c}$, or mouse anti-monkey $\mathrm{IgG}$ at room temperature for $120 \mathrm{~min}$. After washing with

424 PBST three times, TMB substrate buffer was added, followed by incubation at room

425 temperature for $10 \mathrm{~min}$. Then, $1 \mathrm{~N} \mathrm{H}_{2} \mathrm{SO}_{4}$ was added to stop the reaction. OD values at

426450 and 540 or $560 \mathrm{~nm}$ were measured using a spectrophotometer. The reciprocal value

427 of the plasma dilution with $\mathrm{OD}_{450}-\mathrm{OD}_{540}$ or $\mathrm{OD}_{450}-\mathrm{OD}_{560}$ of 0.2 was defined as the

428 antibody titer. 
429 Single-cell suspensions of splenocytes from immunized mice were stimulated by

430 peptide pools $1-8, \mathrm{ECD}$, and RBD protein for 24 hours. IFN- $\gamma$ and IL-13 levels in the

431 supernatant were measured using ELISA (R\&D).

\section{GC B cell and $\mathbf{T}_{\mathbf{F H}}$ staining}

434 Single-cell suspensions of popliteal lymph nodes were stained with LIVE/DEAD Aqua, 435 anti-CD279 (29F.1A12), San Diego, CA, USA), anti-CD8a (53-6.7), anti-CD3e 436 (145-2C11), anti-GL7 (GL7), anti-CD4 (RM4-5), anti-CD185 (L138D7), anti-CD38 437 (90), and anti-CD19 (6D5) antibodies. All antibodies were purchased from BioLegend, 438 San Diego, CA, USA. The percentage of GC B cells and $\mathrm{T}_{\mathrm{FH}}$ cells was analyzed by flow 439 cytometry.

\section{Intracellular staining assay for cytokines}

442 Single-cell suspensions of splenocytes were stimulated with peptide pools 2, 3, and 4 443 together with protein transport inhibitors (eBioscience, San Diego, CA, USA) for $6 \mathrm{~h}$. 444 After stimulation, the cells were stained with LIVE/DEAD Aqua for dead cells. After 445 washing, the cells were stained with anti-CD8a (53-6.7), anti-CD4 (RM4-5: Invitrogen), anti-TCR $\beta$ (H57-597), anti-F4/80 (RM8), anti-TER-119 (TER-119), anti-CD11b

447 (M1/70), anti-CD19 (6D5), anti-CD11c (N418), anti-NK-1.1 (PK136), and 448 anti-CD45R/B220 (RA3-6B2) antibodies. All antibodies were purchased from 449 BioLegend unless otherwise stated. After fixation, permeabilization by IC Fixation 450 Buffer (eBioscience), intracellular cytokines, and CD3 were stained with anti-IFN- $\gamma$ 451 (XMG1.2), anti-IL-2 (JES6-5H4), anti-TNF- $\alpha$ (MP6-XT22), and anti-CD3 (17A2) 452 antibodies. All antibodies were purchased from BioLegend. The percentage of 453 cytokine-producing $\mathrm{CD}^{+}$and $\mathrm{CD} 4^{+} \mathrm{T}$ cells was determined by flow cytometry.

\section{Preparation and stimulation of human peripheral blood mononuclear cells}

456 Peripheral blood mononuclear cells (PBMCs) were obtained from three

457 SARS-CoV-2-uninfected healthy adult volunteers after obtaining informed consent. All 458 experiments using human PBMCs were approved by the Institutional Review Board of 459 the Institute of Medical Science, University of Tokyo. After preparation of PBMCs 460 using Ficoll Histopaque, the cells were stimulated by LNP-mRNA-Full (0.4, 2, and 10 $461 \mu \mathrm{g} / \mathrm{mL}), \mathrm{LNP}-\mathrm{mRNA}-\mathrm{RBD}(0.4,2$, and $10 \mu \mathrm{g} / \mathrm{mL})$, or LNP-mRNA-RBD (HPLC) (0.4, 
4622 , and $10 \mu \mathrm{g} / \mathrm{mL}$ ) for $24 \mathrm{~h}$. IFN- $\alpha$ level in the culture supernatant was measured using

463 ELISA (Mabtech, Stockholm, Sweden).

464

\section{Bone marrow-derived dendritic cells and stimulation}

466 Bone marrow-derived dendritic cells (BM-DCs) were differentiated by culturing for seven days with murine GM-CSF. Cells were stimulated with LNP-mRNA-Full (0.4, 2, and $10 \mu \mathrm{g} / \mathrm{mL}), \mathrm{LNP}-\mathrm{mRNA}-\mathrm{RBD}(0.4,2$, and $10 \mu \mathrm{g} / \mathrm{mL})$, or LNP-mRNA-RBD (HPLC) $(0.4,2$, and $10 \mu \mathrm{g} / \mathrm{mL})$ for $24 \mathrm{~h}$. IFN- $\alpha$ in the culture supernatant was measured using ELISA (Invitrogen).

\section{Neutralization activity against SARS-CoV-2 infection}

473 Thirty-five microliters of virus (140 tissue culture infectious dose 50) was incubated 474 with $35 \mu \mathrm{L}$ of two-fold serial dilutions of sera for $1 \mathrm{~h}$ at room temperature, and $50 \mu \mathrm{L}$ of the mixture was added to confluent VeroE6/TMPRSS2 cells in 96-well plates and incubated for $1 \mathrm{~h}$ at $37^{\circ} \mathrm{C}$. After the addition of $50 \mu \mathrm{L}$ of DMEM containing $5 \% \mathrm{FCS}$, the cells were further incubated for three days at $37^{\circ} \mathrm{C}$. Viral cytopathic effects $(\mathrm{CPE})$ were observed under an inverted microscope, and virus neutralization titers were determined as the reciprocal of the highest serum dilution that completely prevented $\mathrm{CPE}^{24}$.

\section{Virus titration using VeroE6/TMPRSS2 for SARS-CoV-2}

483 Confluent TMPRSS2-expressing Vero E6 cell line (JCRB Cell Bank, Japan) were 484 incubated with diluted swab samples and $10 \% \mathrm{w} / \mathrm{v}$ tissue homogenate samples for $1 \mathrm{~h}$. 485 The cells were washed with HBSS and incubated with DMEM containing $0.1 \%$ BSA 486 for three days ${ }^{25}$. Virus titers were monitored using a microscope and calculated using 487 the Reed-Muench method.

\section{Real-time RT-PCR for viral RNA}

490 Viral RNA from swab samples and tissues (20 mg) was collected using a QIAamp Viral

491 RNA Mini kit and RNeasy Mini Kit, respectively. Viral RNA was measured by

492 real-time RT-PCR (2019-nCoV_N1-F, 2019-nCoV_N1-R, 2019-nCoV_N1-P, and

493 TaqMan Fast Virus 1-step Master Mix) using CFX-96 (Bio-Rad, Hercules, CA, USA). 


\section{Histological evaluation of lung section}

496 Lungs were obtained at autopsy, and 8 lung tissue slices were collected from each

497 macaque: one slice from each upper lobe and middle lobe and two slices from each

498 lower lobe in bilateral lungs. They were fixed in $10 \%$ neutral buffered formalin for

499 approximately $72 \mathrm{~h}$, embedded in paraffin and cut into $3-\mu \mathrm{m}$-thick sections on glass

500 slides. Sections were stained with hematoxylin and eosin (H \& E) and observed under

501 the light microscope. Histological evaluation was performed blindly by two pathologists

502 based on a following criteria established in influenza virus infection ${ }^{26}$ ( 0 : normal lung,

503 1: mild destruction of bronchial epithelium, 2: mild peribronchiolar inflammation, 3:

504 inflammation in the alveolar walls resulting in alveolar thickening, 4: mild alveolar

505 injury accompanied by vascular injury, 5: moderate alveolar injury and vascular injury,

506 6, 7: severe alveolar injury with hyaline membrane-associated alveolar hemorrhage

507 (under or over $50 \%$ of the section area)). The average score of 8 sections was calculated

508 for each macaque, and the mean score of the two pathologists were defined as the

509 histological score. SARS-CoV-2 N antigen was detected by a monoclonal antibody

510 8G8A (Bioss Inc) and secondary antibody following antigen retrieval using autoclave in

511 pH 9 citrate buffer.

\section{Body temperature}

514 Two weeks before virus inoculation, two temperature data loggers (iButton, Maxim

515 Integrated, San Jose, CA) were implanted in the peritoneal cavity of each macaque

516 under ketamine/xylazine anesthesia followed by isoflurane inhalation to monitor body

517 temperature.

\section{X-ray radiography}

520 Chest X-ray radiographs were taken using the I-PACS system (Konica Minolta Inc.,

521 Tokyo, Japan) and PX-20BT mini (Kenko Tokina Corporation, Tokyo, Japan).

\section{Statistical analysis}

524 Statistical significance $(\mathrm{P}<0.05)$ between groups was determined using the

525 Mann-Whitney U test or ANOVA.

\section{Acknowledgments}


528 We thank Fusako Ikeda, Ryoko Suda, Yoko Watanabe, Naomi Sato, Naoko Kitagawa

529 and Hideaki Ishida for technical assistance. This study was supported by AMED under

530 Grant Number JP20fk0108113h0001 and JP20nk0101625h0201.

531

532 Author contribution

533 K.K., M.I., N.J., M.N., S.Y., Y.I., F.T., Y.K., K.J.I., designed research; K.K., M.I., N.J., M.N., K.H., K.I.H.,

534 S.Yamayoshi., J.T., M.I., S.Yamada., T.W., M.K., H.N., H.I., Y.K., C.T.N., Y.I., performed research; K.K.,

535 M.I., M.N., K.H., J.T., B.T., C.T.N., Y.I., analyzed data; N.J., T.N., T.S., F.T., contributed to provide

536 LNP-mRNA vaccine. K.K., N.J., Y.I., Y.K., F.T., K.J.I. wrote the paper.

537

538 Conflict of interest

539 N.J., T.N., T.S., F.T., are employees of Daichi Sankyo Co., Ltd.

540 K.K., M.I., N.J., S.Yamayoshi., T.N., T.S., F.T., Y.K., K.J.I. are inventors on patent

541 application related to the content of this manuscript.

542

543 References

544

5451 Baden, L. R. et al. Efficacy and Safety of the mRNA-1273 SARS-CoV-2

$546 \quad$ Vaccine. N Engl J Med, doi:10.1056/NEJMoa2035389 (2020).

5472 Polack, F. P. et al. Safety and Efficacy of the BNT162b2 mRNA

$548 \quad$ Covid-19 Vaccine. N Engl J Med 383, 2603-2615,

549 doi:10.1056/NEJMoa2034577 (2020).

5503 Lan, J. et al. Structure of the SARS-CoV-2 spike receptor-binding

551 domain bound to the ACE2 receptor. Nature 581, 215-220,

552 doi:10.1038/s41586-020-2180-5 (2020).

5534 Rydyznski Moderbacher, C. et al. Antigen-Specific Adaptive Immunity 554 to SARS-CoV-2 in Acute COVID-19 and Associations with Age and

555 Disease Severity. Cell 183, 996-1012 e1019,

$556 \quad$ doi:10.1016/j.cell.2020.09.038 (2020).

$5575 \quad$ McMahan, K. et al. Correlates of protection against SARS-CoV-2 in

558 rhesus macaques. Nature, doi:10.1038/s41586-020-03041-6 (2020).

5596 Vogel, A. B. et al. BNT162b vaccines are immunogenic and protect

560 non-human primates against SARS-CoV-2. bioRxiv, 
2020.2012.2011.421008, doi:10.1101/2020.12.11.421008 (2020).

$5627 \quad$ Zhou, P. et al. A pneumonia outbreak associated with a new

563 coronavirus of probable bat origin. Nature 579, 270-273,

564 doi:10.1038/s41586-020-2012-7 (2020).

5658 Jackson, L. A. et al. An mRNA Vaccine against SARS-CoV-2 -

566 Preliminary Report. N Engl J Med 383, 1920-1931,

567 doi:10.1056/NEJMoa2022483 (2020).

5689 Anderson, E. J. et al. Safety and Immunogenicity of SARS-CoV-2 mRNA-1273 Vaccine in Older Adults. N Engl J Med 383, 2427-2438, doi:10.1056/NEJMoa2028436 (2020).

571

10 Walsh, E. E. et al. Safety and Immunogenicity of Two RNA-Based

572 Covid-19 Vaccine Candidates. N Engl J Med 383, 2439-2450,

573 doi:10.1056/NEJMoa2027906 (2020).

57411 Elia, U. et al. Design of SARS-CoV-2 RBD mRNA Vaccine Using Novel

575

576 Ionizable Lipids. bioRxiv, 2020.2010.2015.341537, doi:10.1101/2020.10.15.341537 (2020).

Tai, W. et al. A novel receptor-binding domain (RBD)-based mRNA vaccine against SARS-CoV-2. Cell Res 30, 932-935, doi:10.1038/s41422-020-0387-5 (2020).

Lederer, K. et al. SARS-CoV-2 mRNA Vaccines Foster Potent doi:10.1016/j.immuni.2020.11.009 (2020).

Desmet, C. J. \& Ishii, K. J. Nucleic acid sensing at the interface between innate and adaptive immunity in vaccination. Nat ReV

Immunol 12, 479-491, doi:10.1038/nri3247 (2012).

58715 Coban, C. et al. Novel strategies to improve DNA vaccine immunogenicity. Curr Gene Ther 11, 479-484, doi:10.2174/156652311798192815 (2011).

59016 Pardi, N., Hogan, M. J., Porter, F. W. \& Weissman, D. mRNA vaccines 591 a new era in vaccinology. Nat Rev Drug Discov 17, 261-279, 592 doi:10.1038/nrd.2017.243 (2018).

59317 Iavarone, C., O'Hagan D, T., Yu, D., Delahaye, N. F. \& Ulmer, J. B. 
Mechanism of action of mRNA-based vaccines. Expert Rev Vaccines 16, 871-881, doi:10.1080/14760584.2017.1355245 (2017).

59618 Kariko, K., Buckstein, M., Ni, H. \& Weissman, D. Suppression of RNA 597 recognition by Toll-like receptors: the impact of nucleoside modification and the evolutionary origin of RNA. Immunity 23, 165-175, doi:10.1016/j.immuni.2005.06.008 (2005).

60019 Kariko, K. et al. Incorporation of pseudouridine into mRNA yields

601 superior nonimmunogenic vector with increased translational

602 capacity and biological stability. Mol Ther 16, 1833-1840,

603 doi:10.1038/mt.2008.200 (2008).

60420 Kariko, K., Muramatsu, H., Ludwig, J. \& Weissman, D. Generating

605

606 the optimal mRNA for therapy: HPLC purification eliminates immune activation and improves translation of nucleoside-modified,

608 protein-encoding mRNA. Nucleic Acids Res 39, e142, doi:10.1093/nar/gkr695 (2011).

21 De Beuckelaer, A. et al. Type I Interferons Interfere with the Capacity of mRNA Lipoplex Vaccines to Elicit Cytolytic T Cell Responses. Mol Ther 24, 2012-2020, doi:10.1038/mt.2016.161 (2016). doi:10.1016/j.molmed.2019.10.002 (2020). SARS-CoV-2 in Nonhuman Primates. N Engl J Med 383, 1544-1555, doi:10.1056/NEJMoa2024671 (2020).

61924 Imai, M. et al. Syrian hamsters as a small animal model for SARS-CoV-2 infection and countermeasure development. Proc Natl Acad Sci U S A 117, 16587-16595, doi:10.1073/pnas.2009799117

62325 Ishigaki, H. et al. Neutralizing antibody-dependent and -independent immune responses against SARS-CoV-2 in cynomolgus macaques. Virology 554, 97-105, doi:10.1016/j.virol.2020.12.013 (2021).

62626 Ogiwara, H. et al. Histopathological evaluation of the diversity of cells 
bioRxiv preprint doi: https://doi.org/10.1101/2021.03.04.433852; this version posted March 4, 2021. The copyright holder for this preprint (which was not certified by peer review) is the author/funder, who has granted bioRxiv a license to display the preprint in perpetuity. It is made available under aCC-BY-NC-ND 4.0 International license. 
bioRxiv preprint doi: https://doi.org/10.1101/2021.03 .04.433852; this version posted March 4, 2021. The copyright holder for this preprint (which was not certified by peer review) is the author/funder, who has granted bioRxiv a license to display the preprint in perpetuity. It is made available under aCC-BY-NC-ND 4.0 International license.
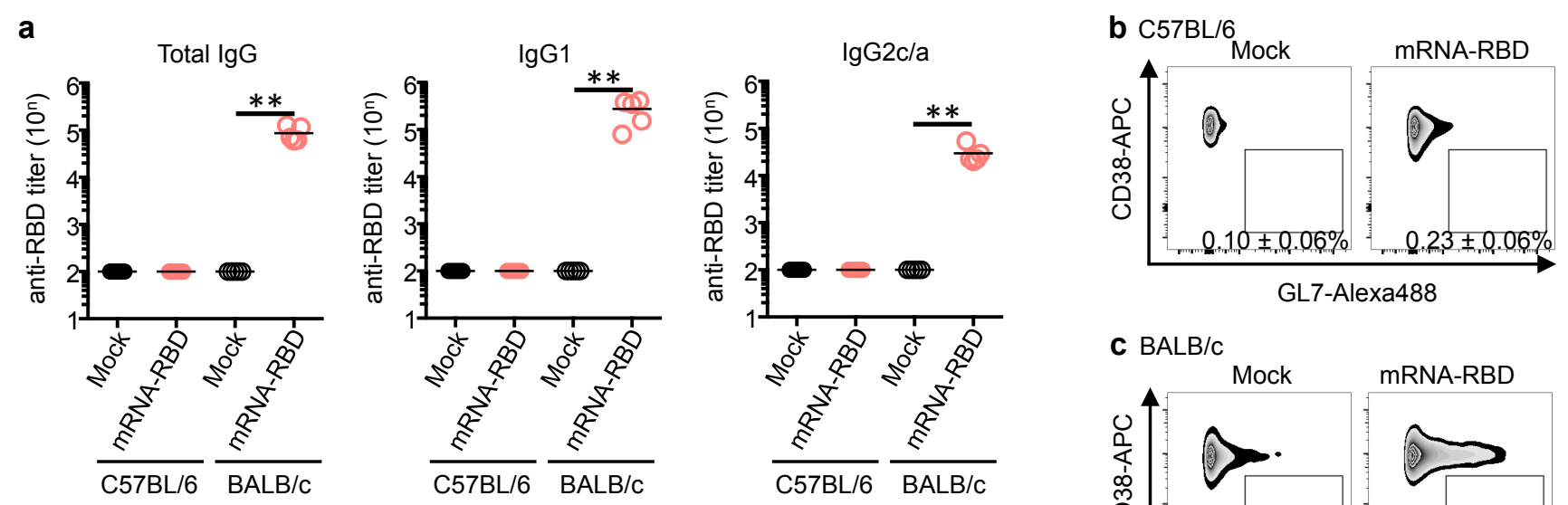

C $B A L B / c$
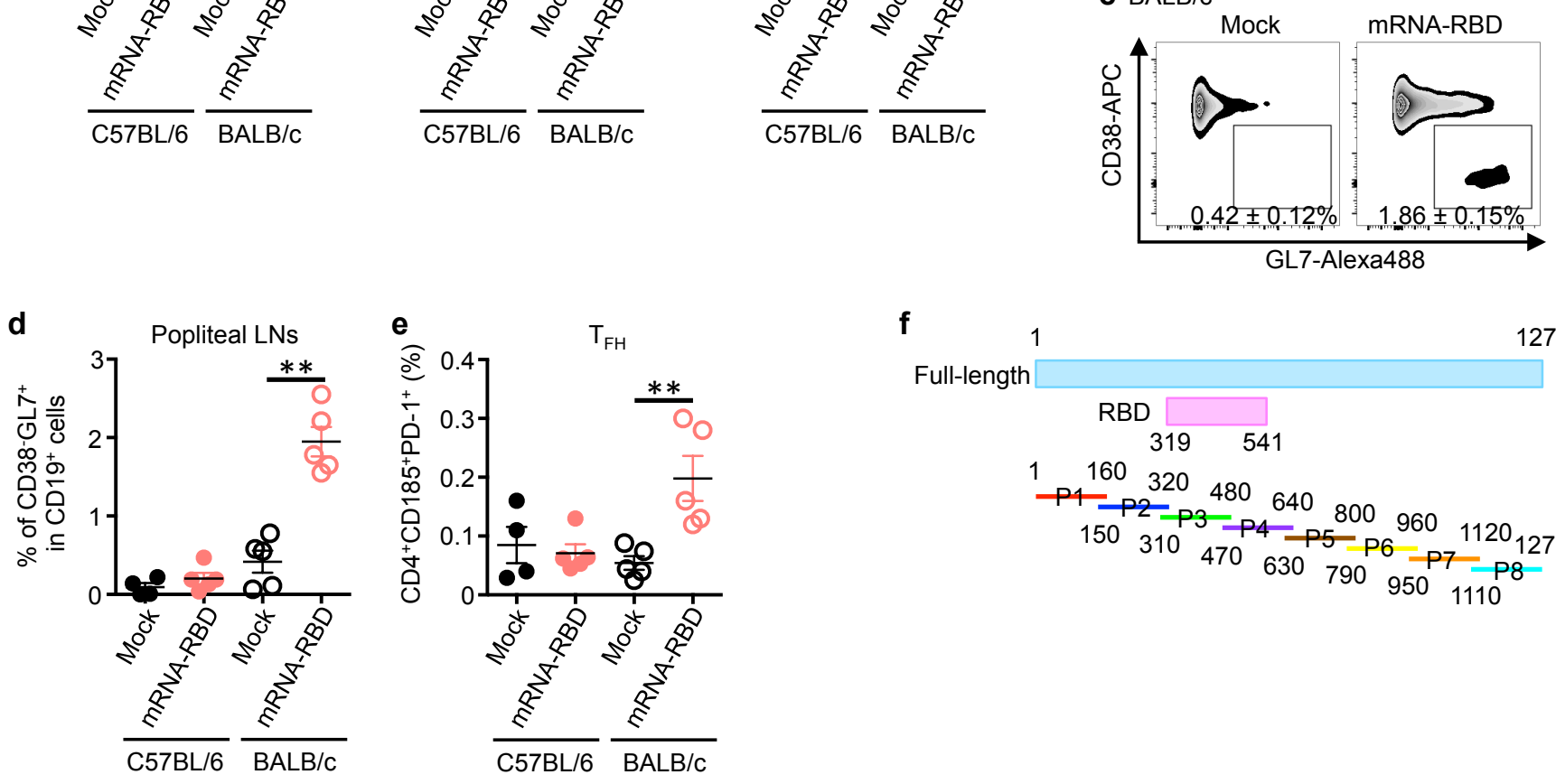

f
Full-length

1273

g

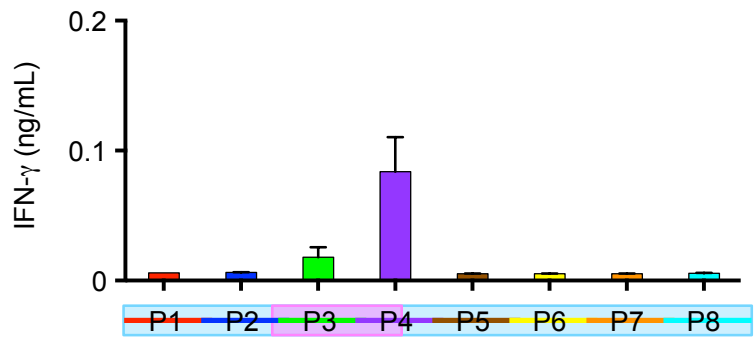

ICS (CD8 ${ }^{+} \mathrm{T}$ cells)

Total $(\%)=0.27 \quad 0.34 \quad 0.32$

ICS (CD4 ${ }^{+} \mathrm{T}$ cells)

Total $(\%)=0.09 \quad 0.13 \quad 0.08$

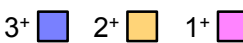

h

BALB/c: mRNA-RBD

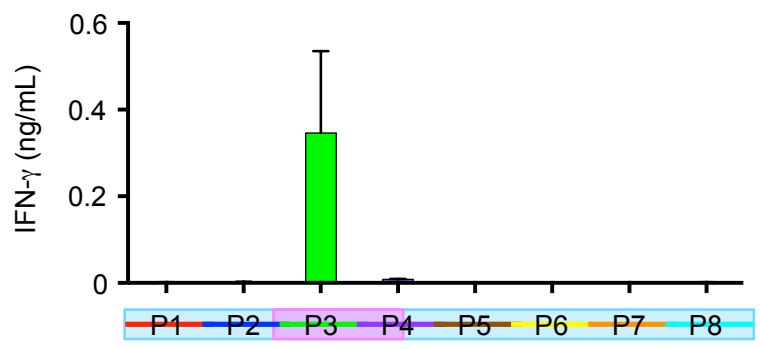

ICS (CD8 ${ }^{+} \mathrm{T}$ cells)

Total $(\%)=0.20 \quad 0.29 \quad 0.28$

ICS (CD4 ${ }^{+} \mathrm{T}$ cells $)$

Total $(\%)=0.20 \quad 0.43 \quad 0.19$

Figure. 1 

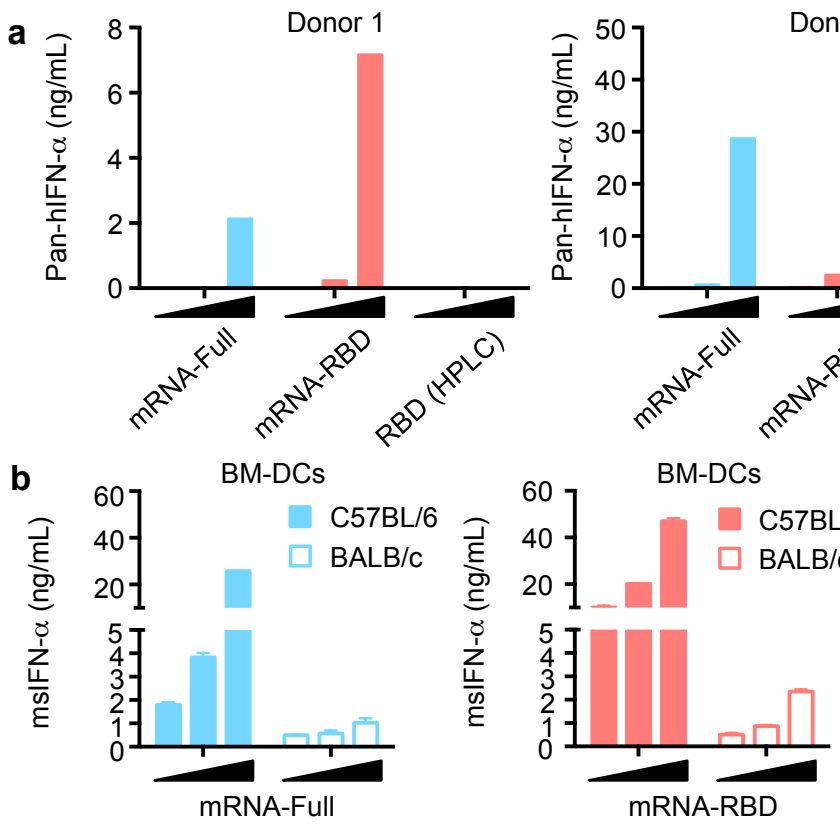
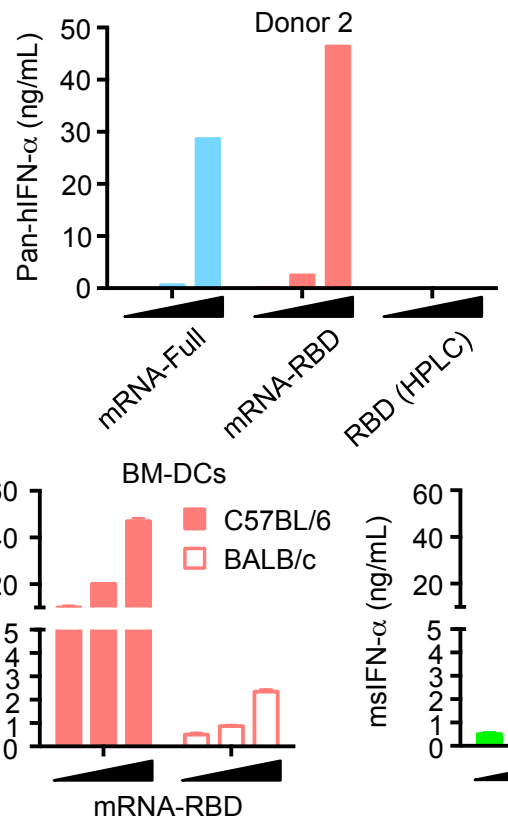

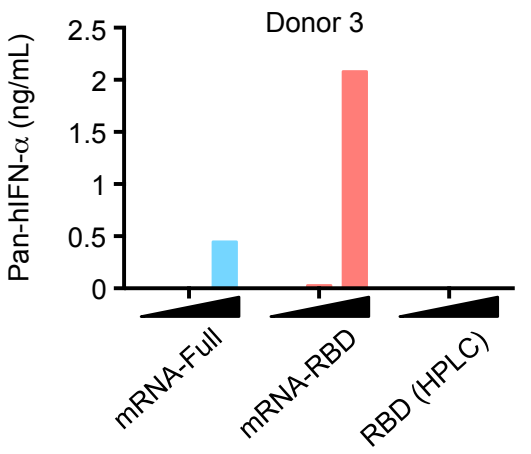

BM-DCs

$\square \mathrm{BALB} / \mathrm{C}$
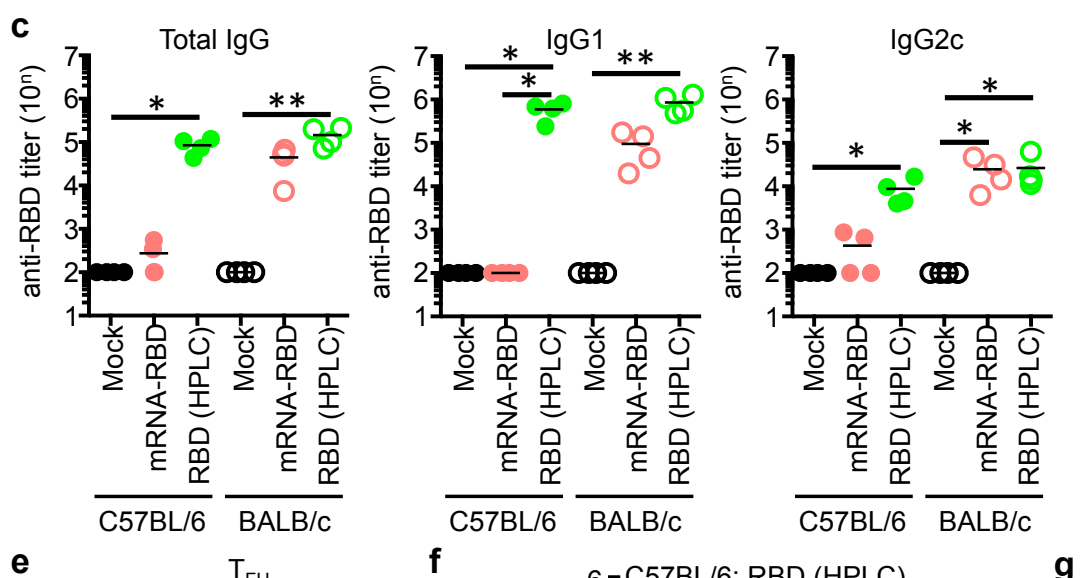

d Popliteal LNs
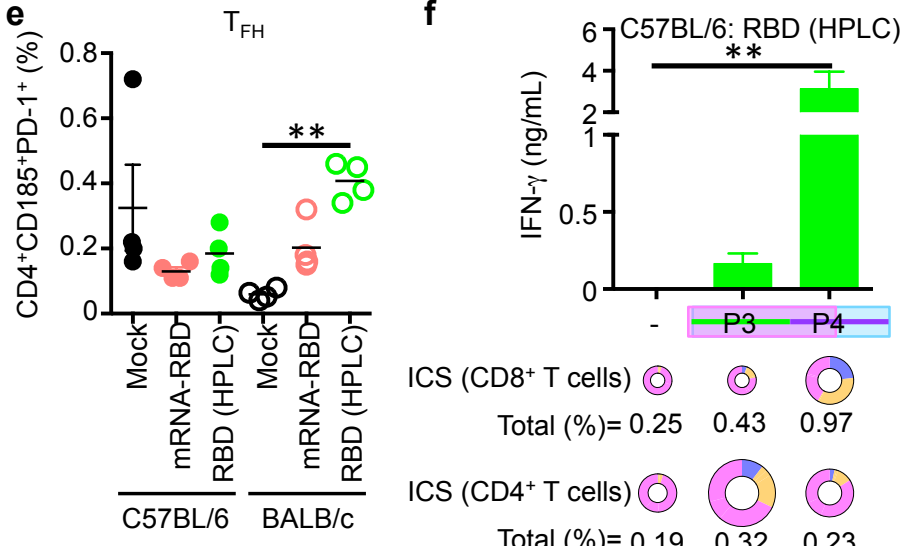

Total $(\%)=0.25 \quad 0.43 \quad 0.97$

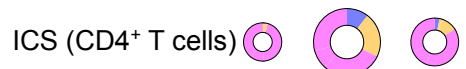

Total $(\%)=0.19 \quad 0.32 \quad 0.23$
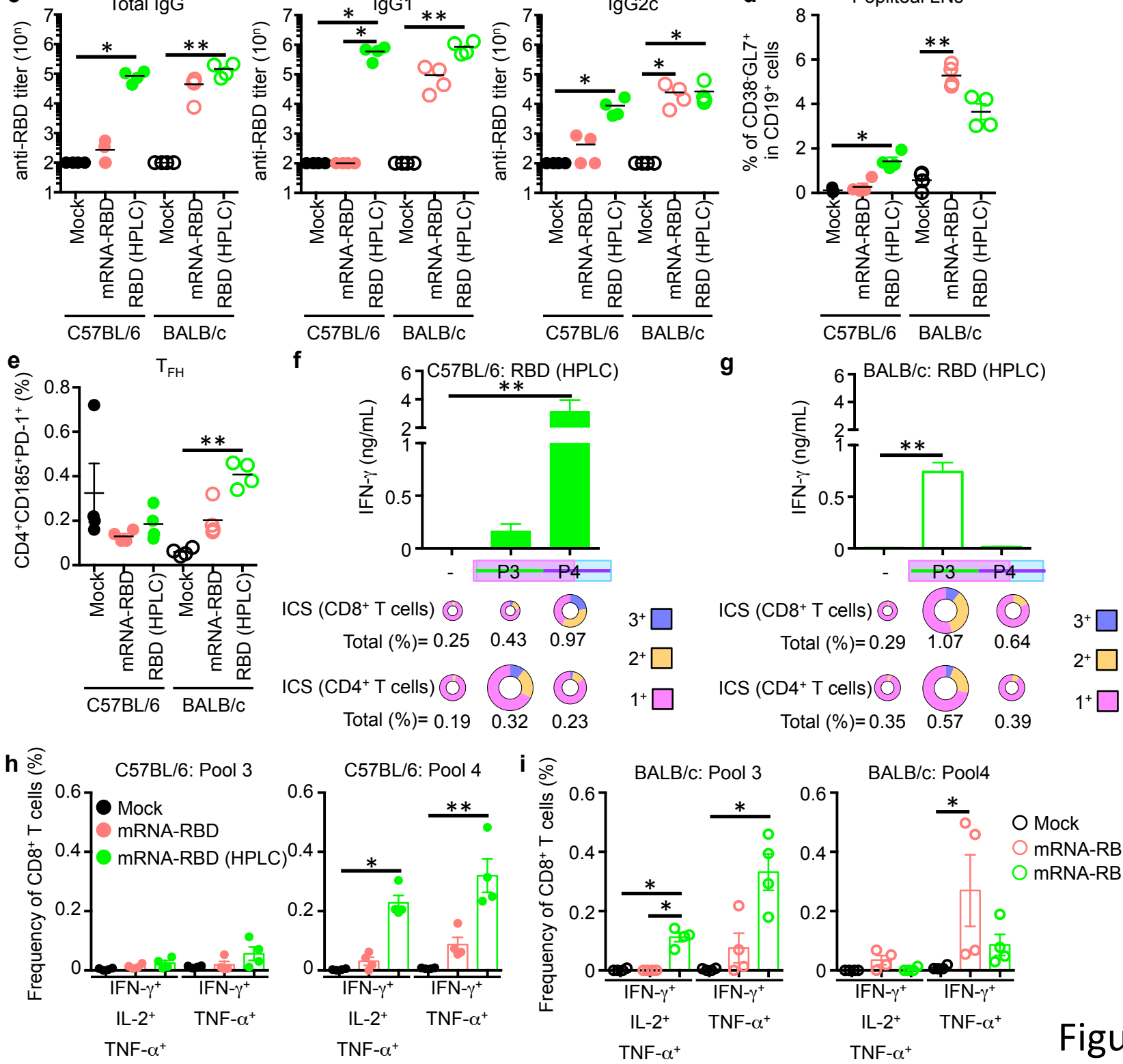

Total $(\%)=0.35 \quad 0.57 \quad 0.39$

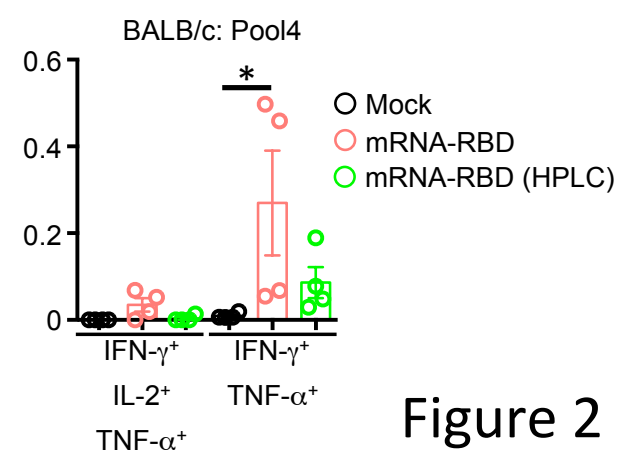


bioRxiv preprint doi: https://doi org/10 1101/2021.03 04 433852. this version posted March 4, 2021. The copyright holder for this preprint (which was not certified by peer review) is the author/funder, who has granted bioRxiv a license to display the preprint in perpetuity. It is made available under aCC-BY-NC-ND 4.0 International license.

a Cynomolgus Monkey

Prime-Boost
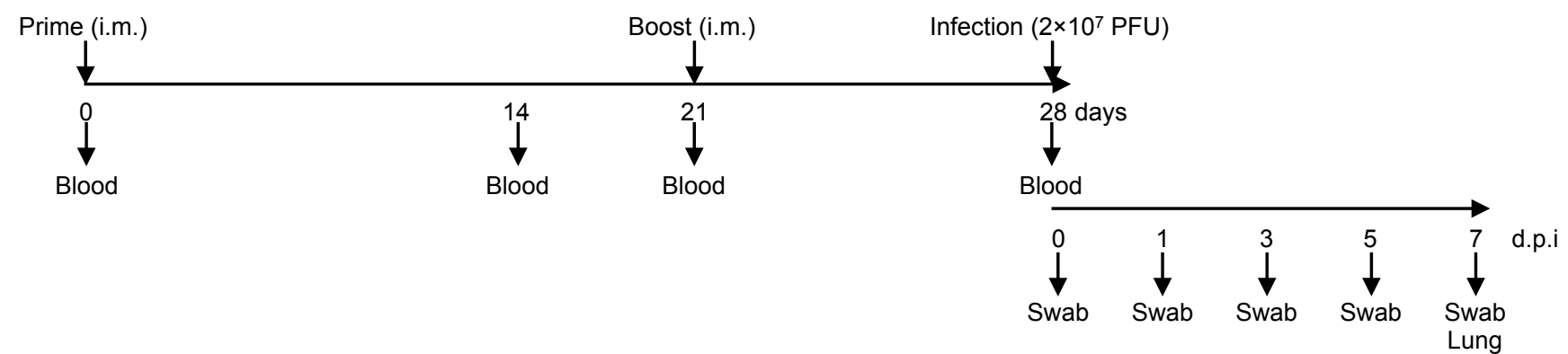

b

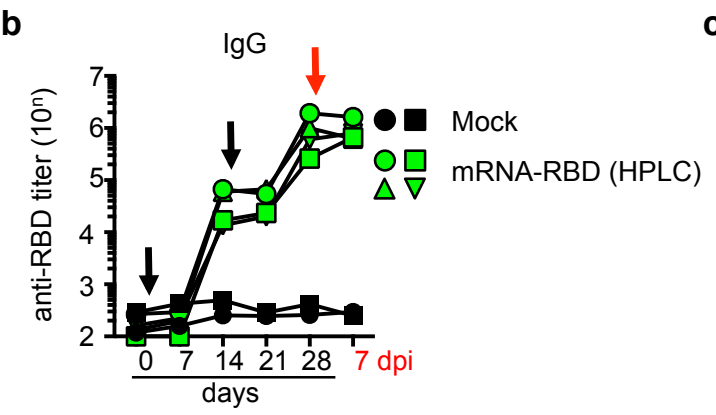

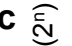

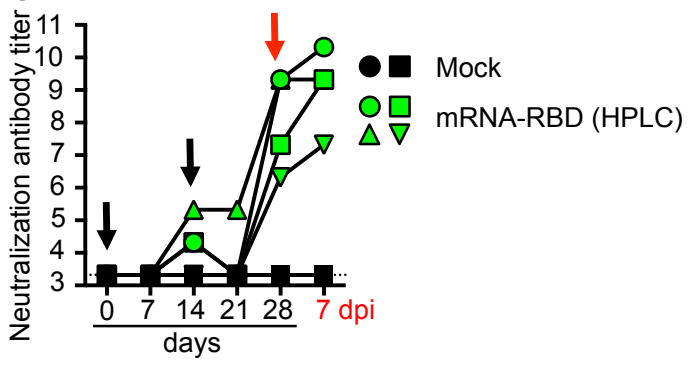

d

Conjunctiva: IgG

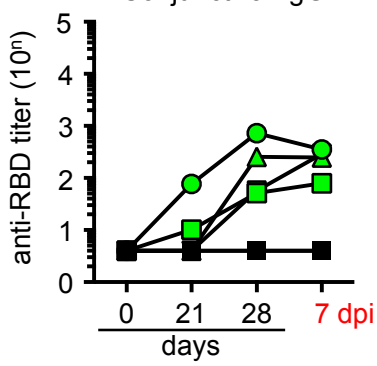

Trachea: $\lg G$

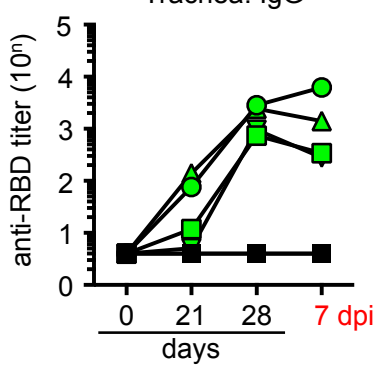

Nasal: $\lg G$

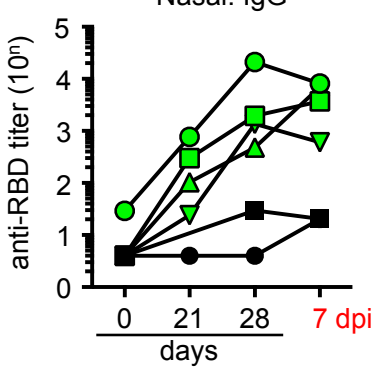

Rectum: $\lg G$

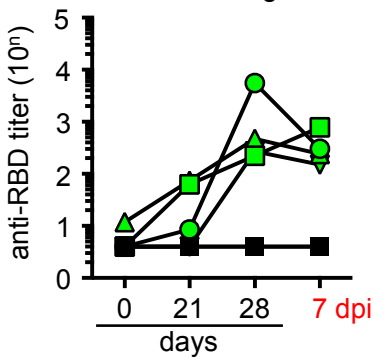

Oral: $\lg G$

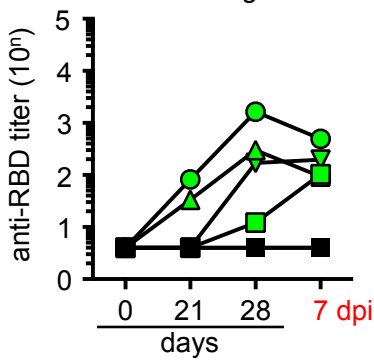

Mock

$\triangle{ }_{\triangle}$ mRNA-RBD (HPLC) 
bioRxiv preprint doi: https://doi.org/10.1101/2021.03.04 433852. this version posted March 4 2021. The copyright holder for this preprint (which was not certified by peer review) is the author/funder, who has granted bioRxiv a license to display the preprint in perpetuity. It is made available under aCC-BY-NC-ND 4.0 International license.
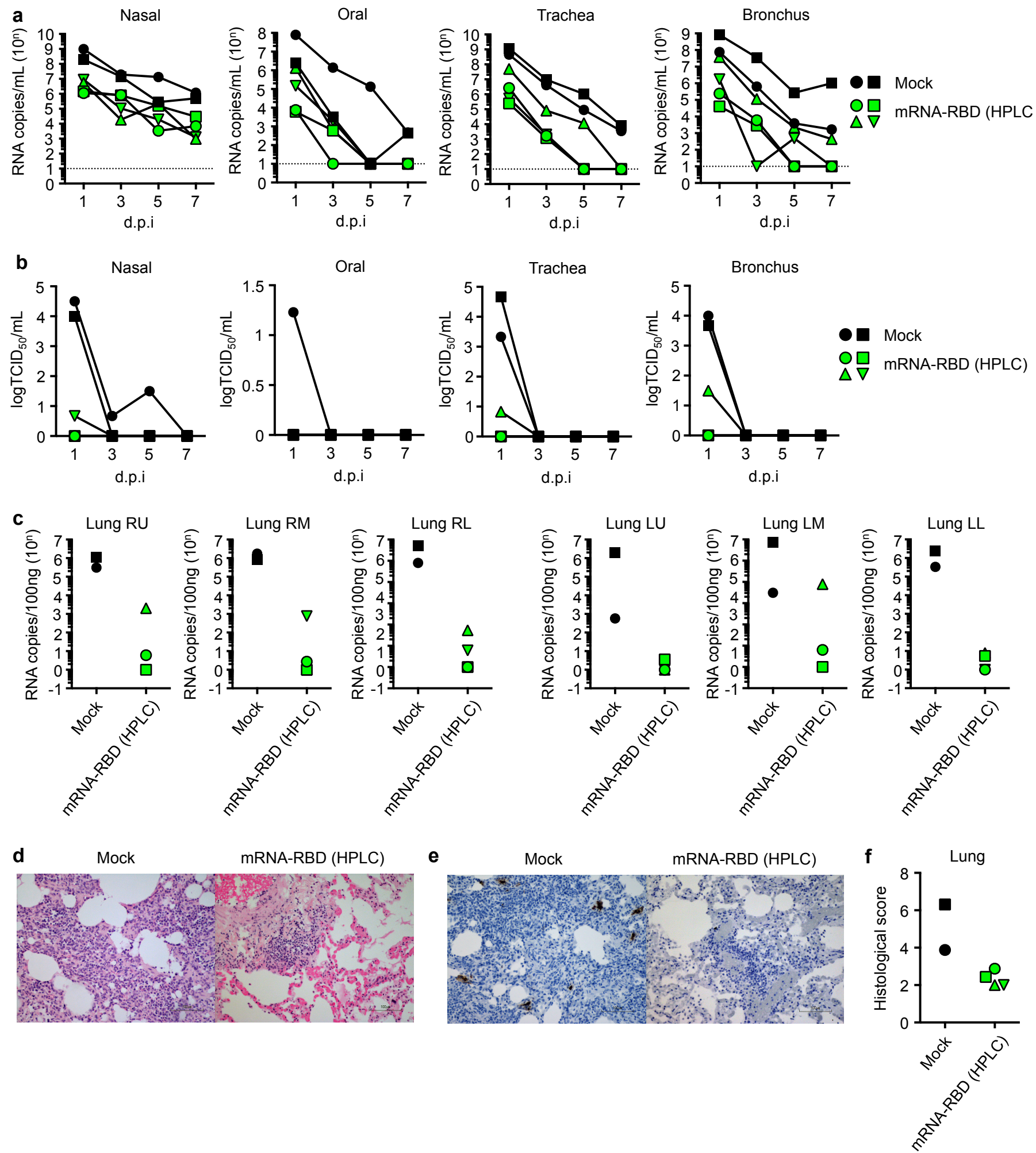

Figure 4 
bioRxiv preprint doi: https://doi.org/10.1101/2021.03.04.433852; this version posted March 4, 2021. The copyright holder for this preprint (which was not certified by peer review) is the author/funder, who has granted bioRxiv a license to display the preprint in perpetuity. It is made available under aCC-BY-NC-ND 4.0 International license.

a
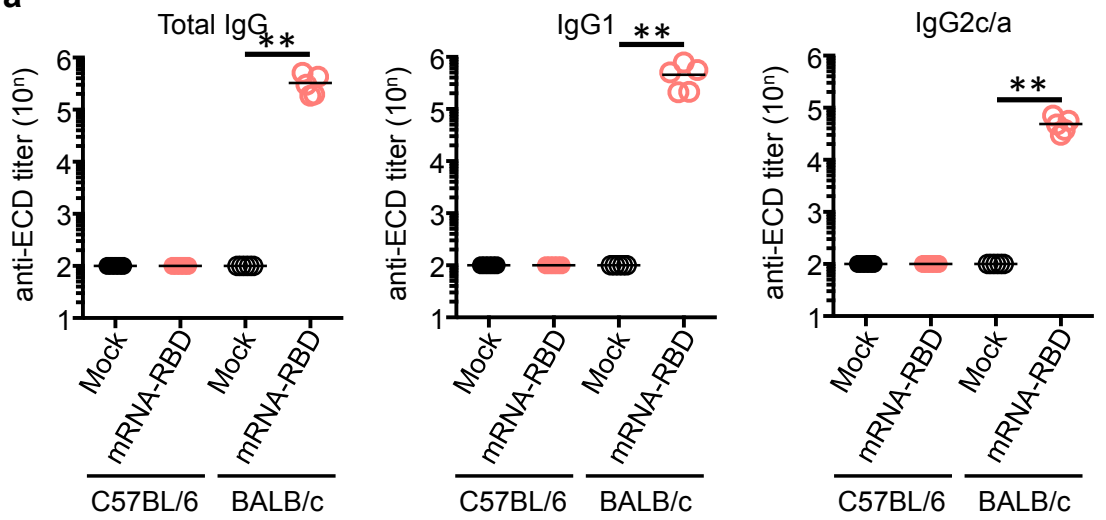
bioRxiv preprint doi: https://doi.org/10.1101/2021.03.04.433852; this version posted March 4, 2021. The copyright holder for this preprint (which was not certified by peer review) is the author/funder, who has granted bioRxiv a license to display the preprint in perpetuity. It is made available under aCC-BY-NC-ND 4.0 International license.

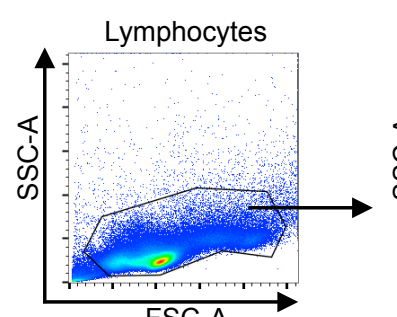

FSC-A

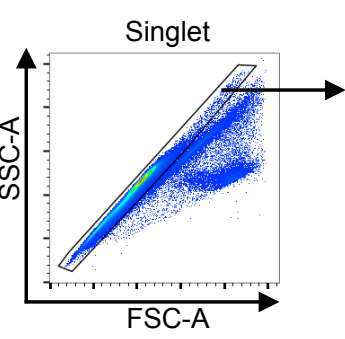

$\mathrm{CD}^{+} \mathrm{T}$ cells
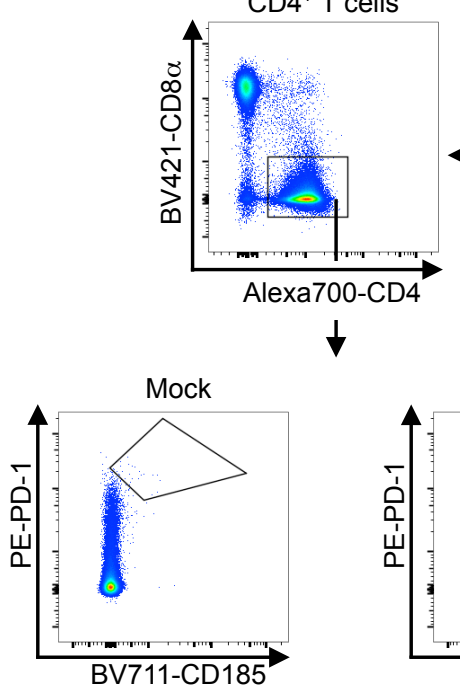

$\overrightarrow{B V 711-C D 185}$

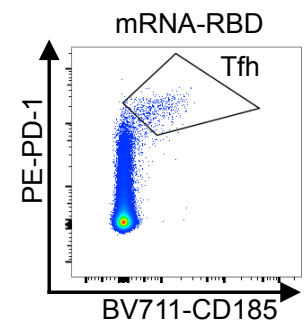

BV711-CD185
Singlet

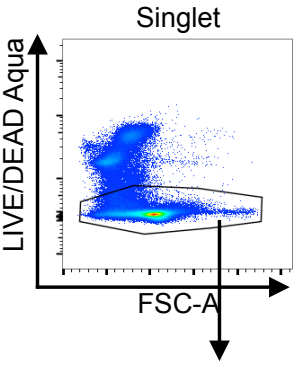

FSC-A
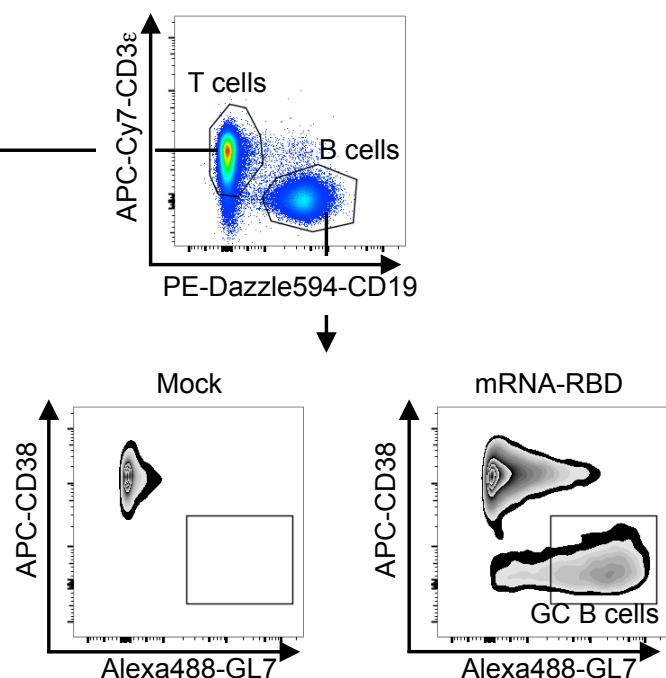
bioRxiv preprint doi: https://doi.org/10.1101/2021.03.04.433852; this version posted March 4, 2021. The copyright holder for this preprint (which was not certified by peer review) is the author/funder, who has granted bioRxiv a license to display the preprint in perpetuity. It is made available under aCC-BY-NC-ND 4.0 International license.

a

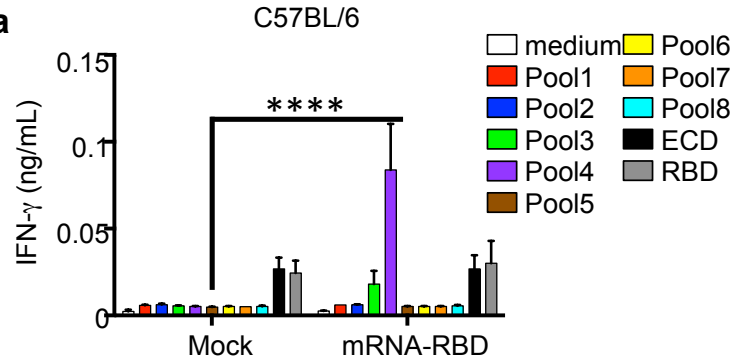

C

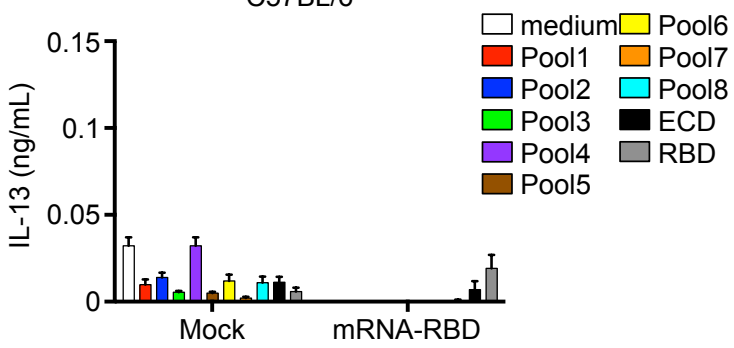

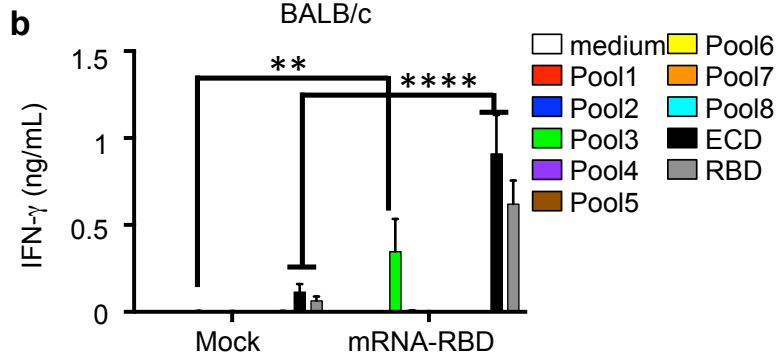

d $\quad B A L B / c$

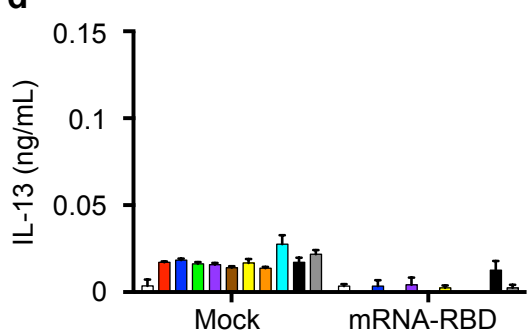


bioRxiv preprint doi: https://doi.org/10.1101/2021.03.04.433852; this version posted March 4, 2021. The copyright holder for this preprint (which was not certified by peer review) is the author/funder, who has granted bioRxiv a license to display the preprint in perpetuity. It is made available under aCC-BY-NC-ND 4.0 International license.

a
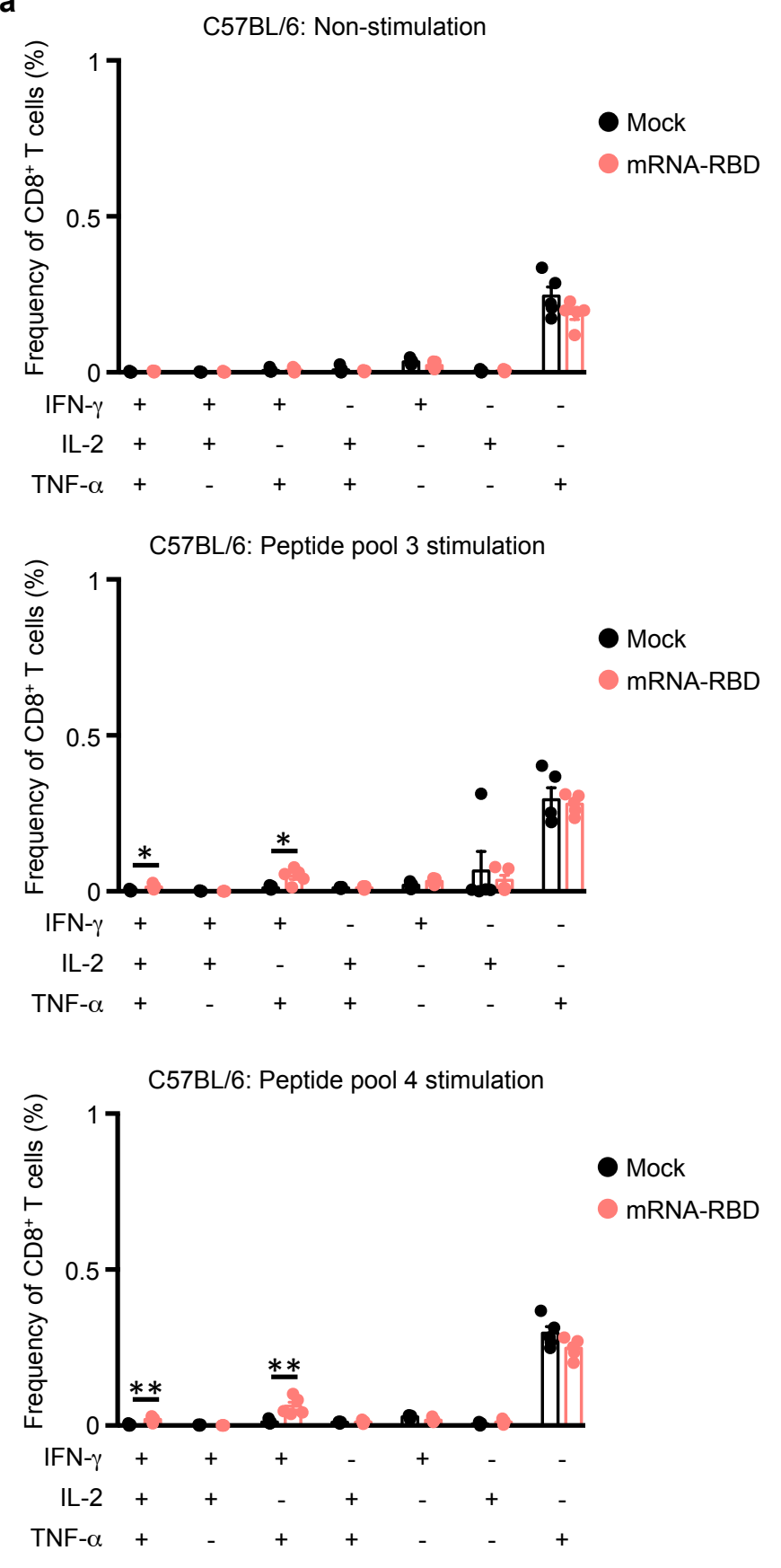

b

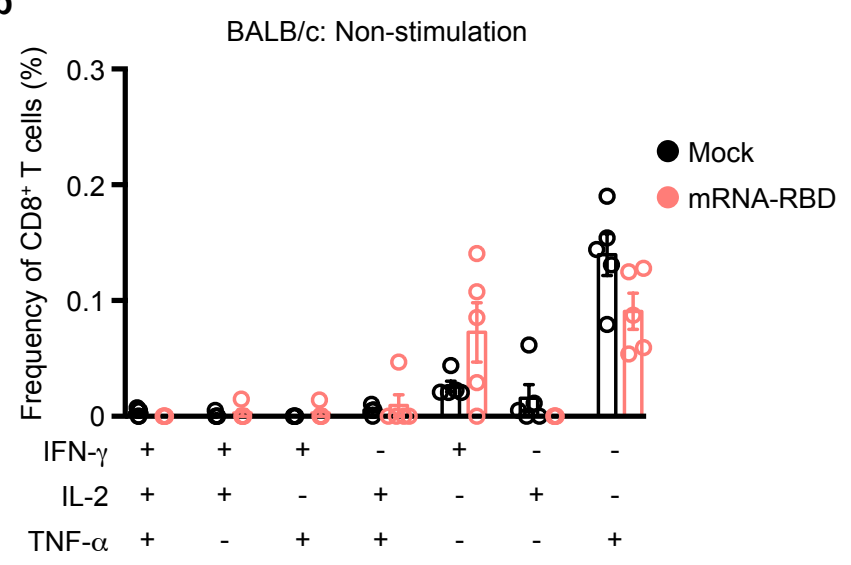

BALB/c: Peptide pool 3 stimulation

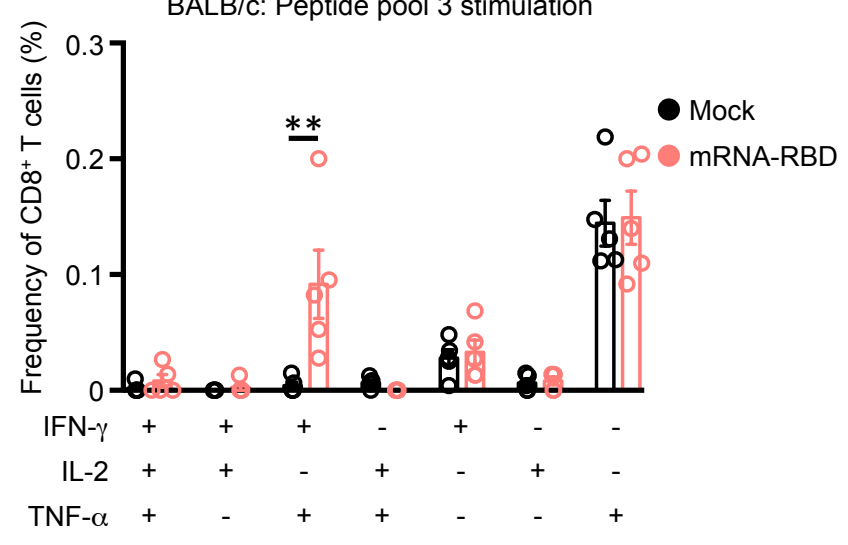

BALB/c: Peptide pool 4 stimulation

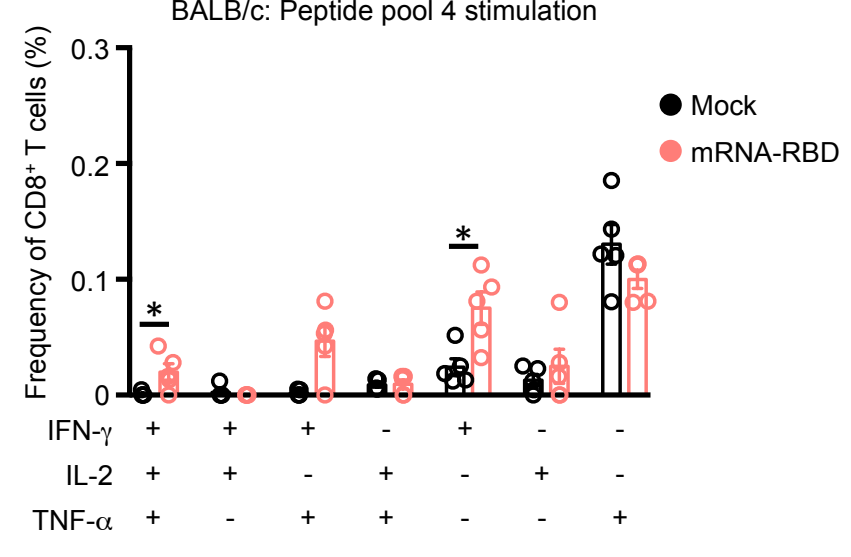


bioRxiv preprint doi: $\mathrm{https} / /$ doi.org/10.1101/2021.03 .04.433852; this version posted March 4, 2021. The copyright holder for this preprint (which was not certified by peer review) is the author/funder, who has granted bioRxiv a license to display the preprint in perpetuity. It is made available under aCC-BY-NC-ND 4.0 International license.

a

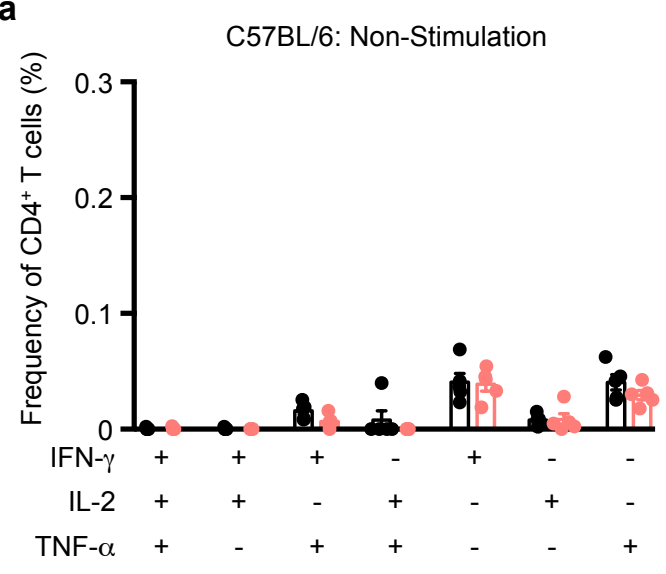

C57BL/6: Peptide pool 3 stimulation

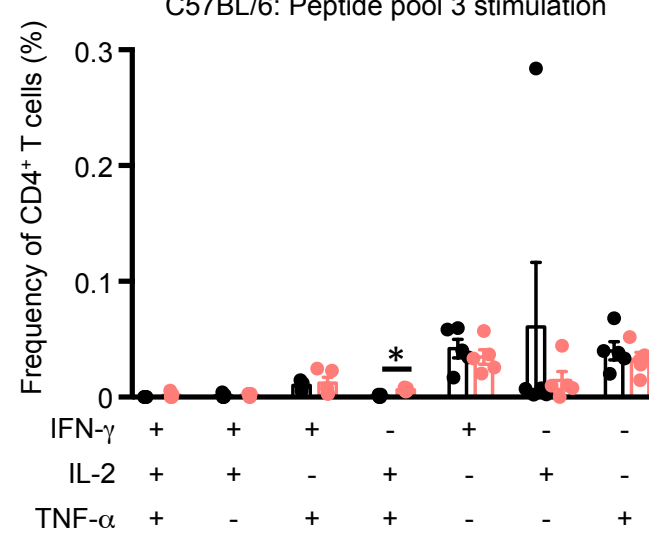

C57BL/6: Peptide pool 4 stimulation

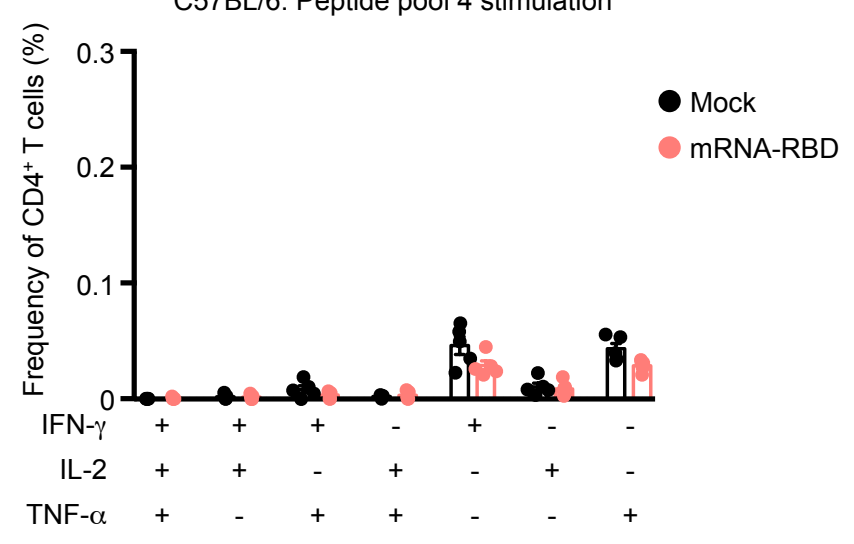

Mock

mRNA-RBD

- Mock

mRNA-RBD

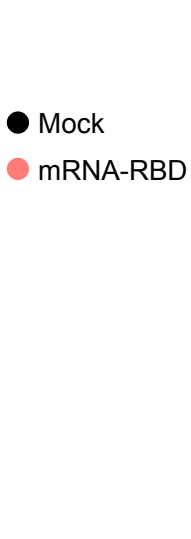

b
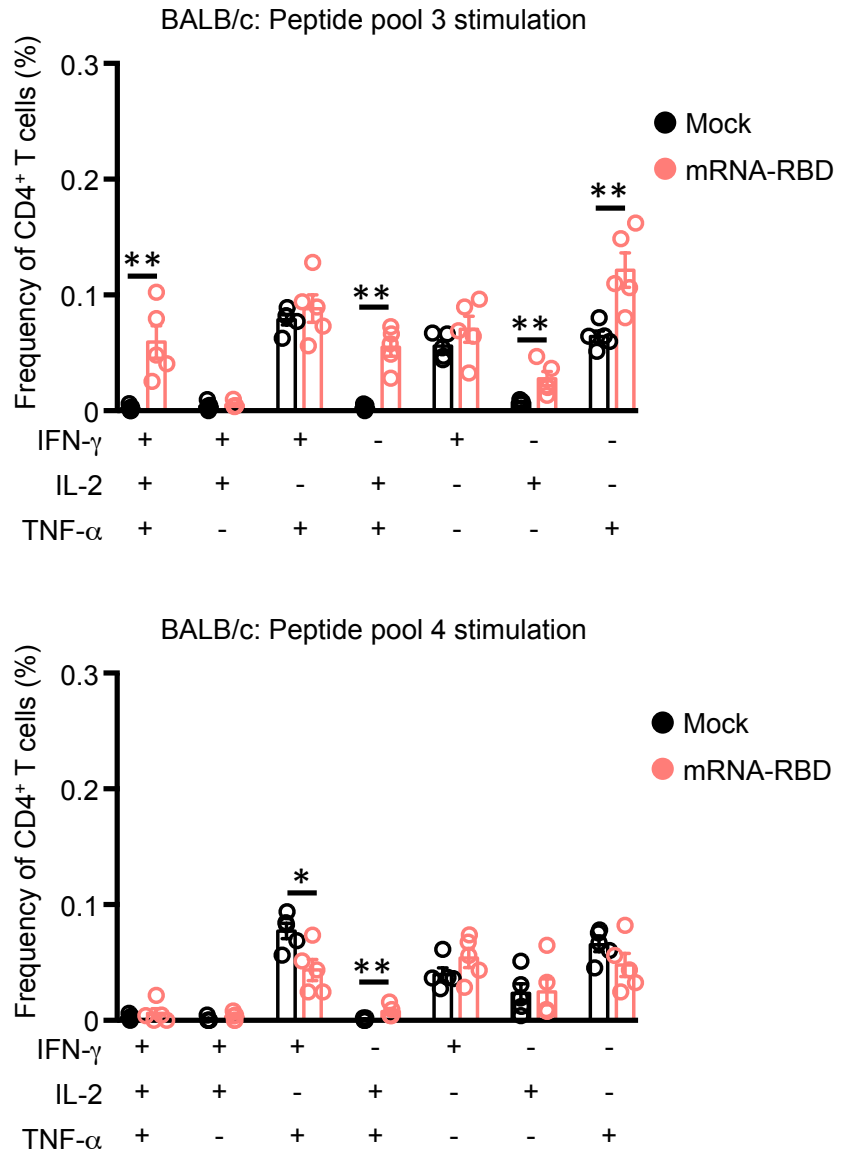
bioRxiv preprint doi: https://doi.org/10.1101/2021.03.04.433852; this version posted March 4, 2021. The copyright holder for this preprint (which was not certified by peer review) is the author/funder, who has granted bioRxiv a license to display the preprint in perpetuity. It is made available under aCC-BY-NC-ND 4.0 International license.
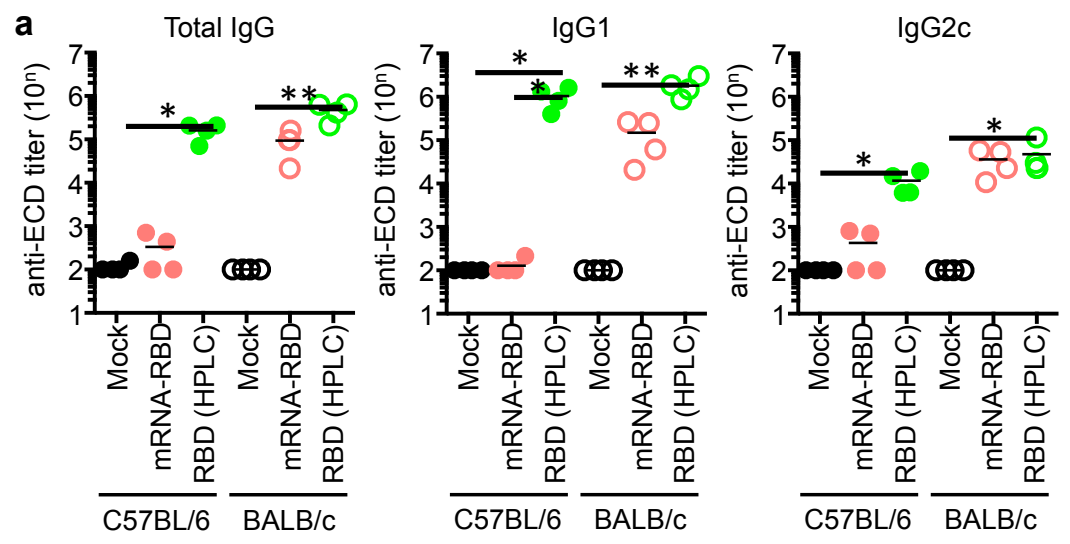

b

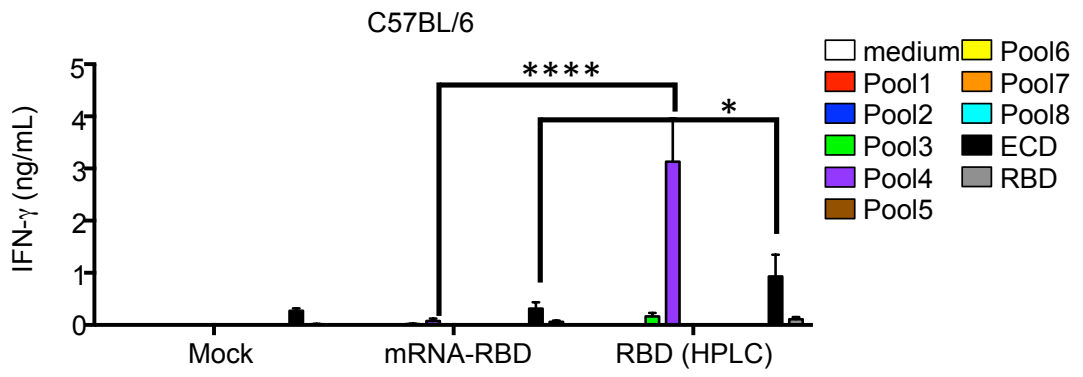

C

C57BL/6

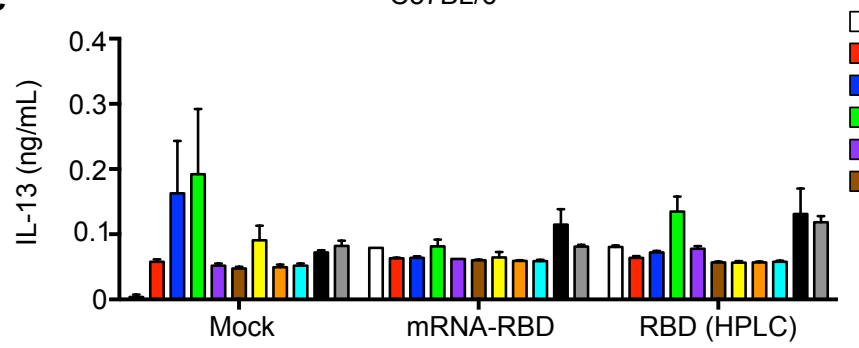

d

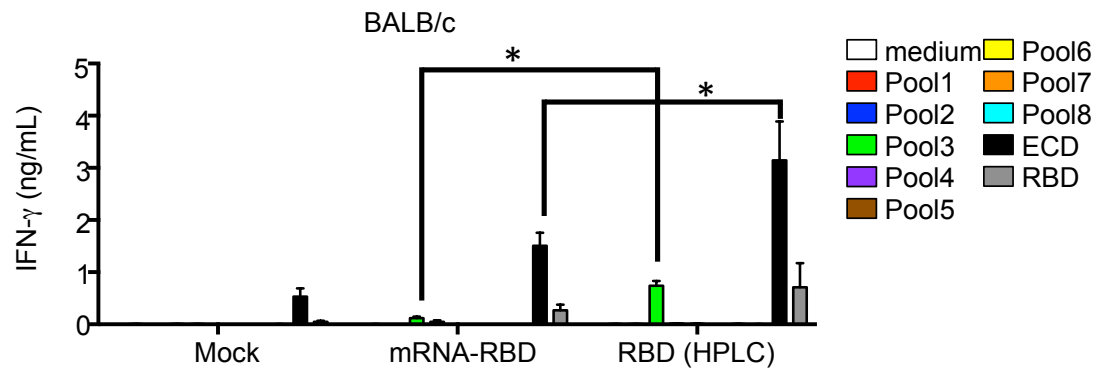

e

$\mathrm{BALB} / \mathrm{c}$

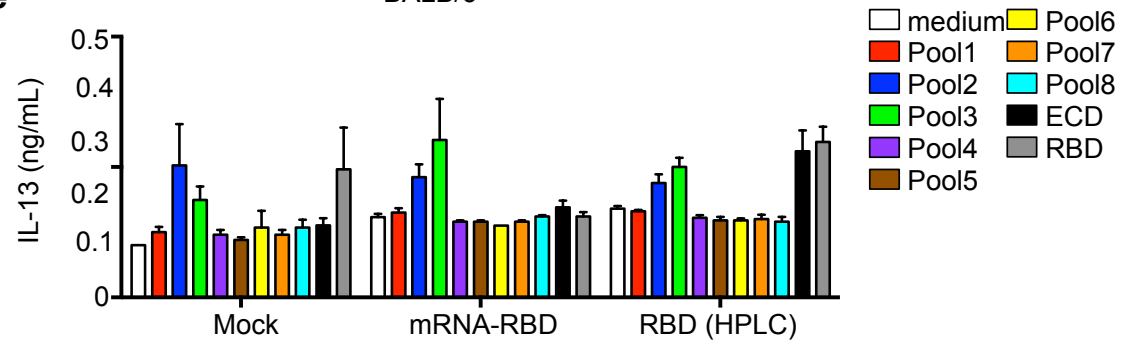


bioRxiv preprint doi: https:/doi.org/10.1101/2021.03.04.433852; this version posted March 4, 2021. The copyright holder for this preprint
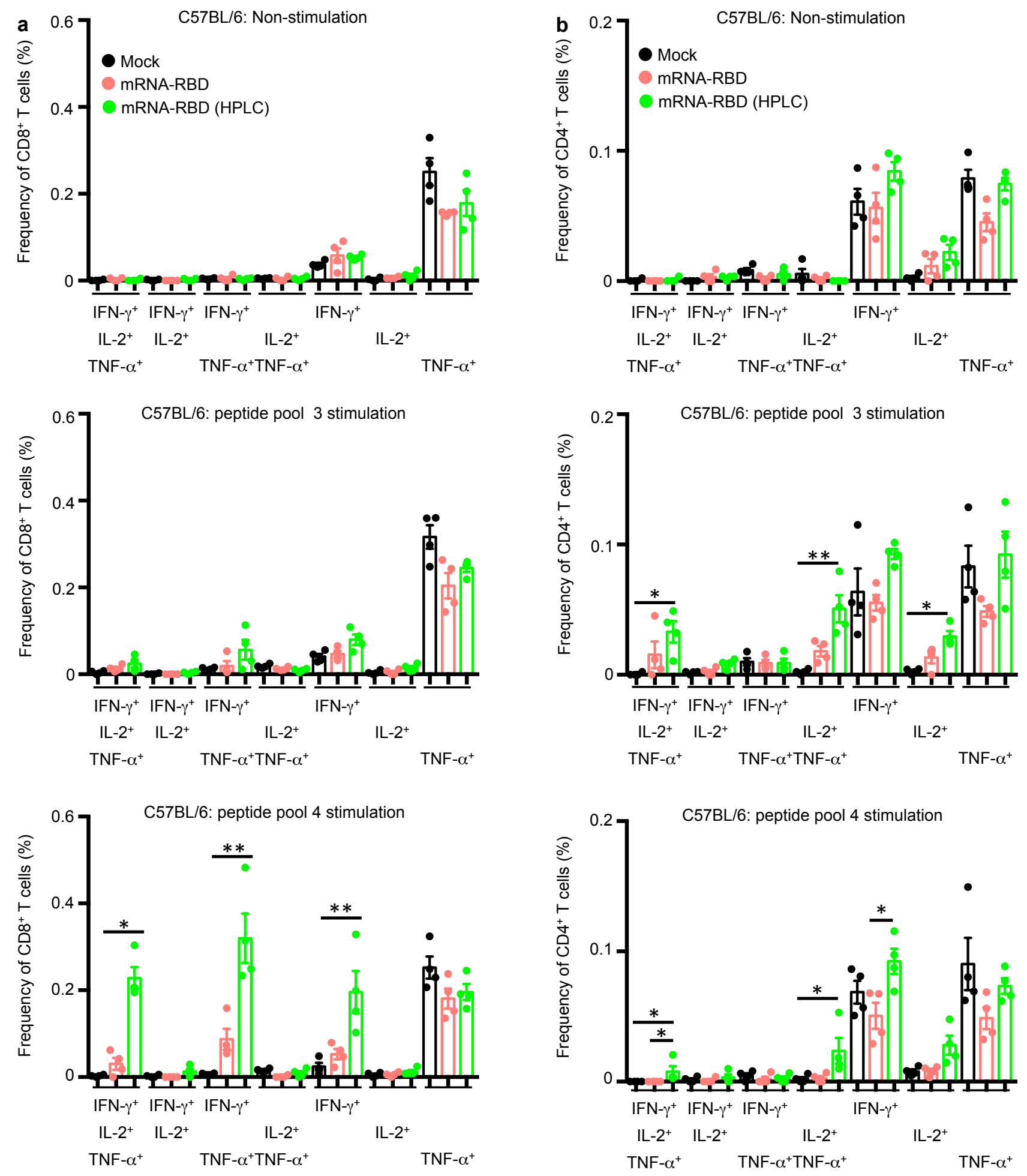
bioRxiv preprint doi: https:/doi.org/10.1101/2021.03 .04.433852; this version posted March 4, 2021. The copyright holder for this preprint (which was not certified by peer review) is the author/funder, who has granted bioRxiv a license to display the preprint in perpetuity. It is made available under aCC-BY-NC-ND 4.0 International license.
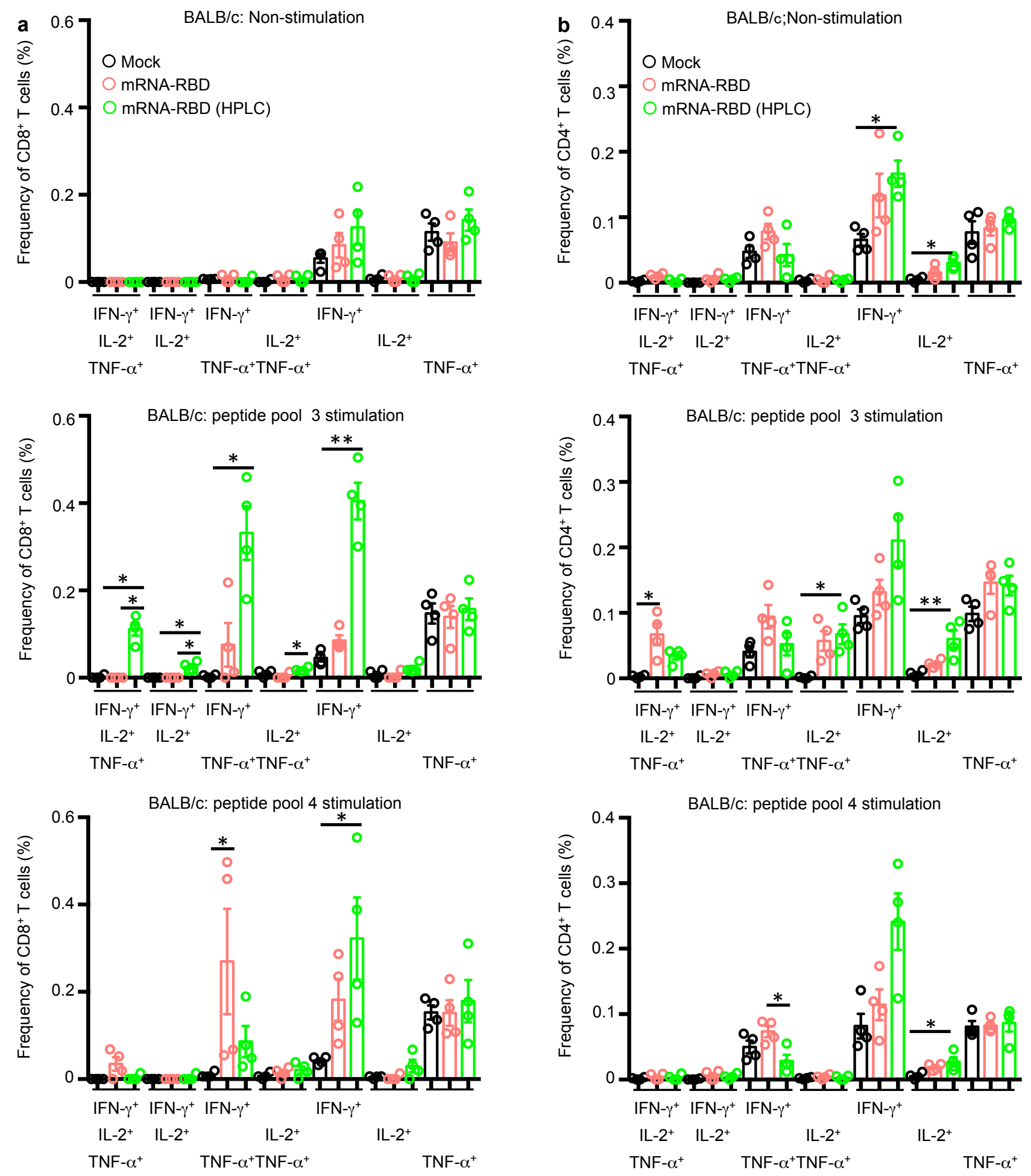

Extended data Fig. 8 
bioRxiv preprint doi: https://doi.org/10.1101/2021.03.04.433852; this version posted March 4, 2021. The copyright holder for this preprint (which was not certified by peer review) is the author/funder, who has granted bioRxiv a license to display the preprint in perpetuity. It is made available under aCC-BY-NC-ND 4.0 International license.
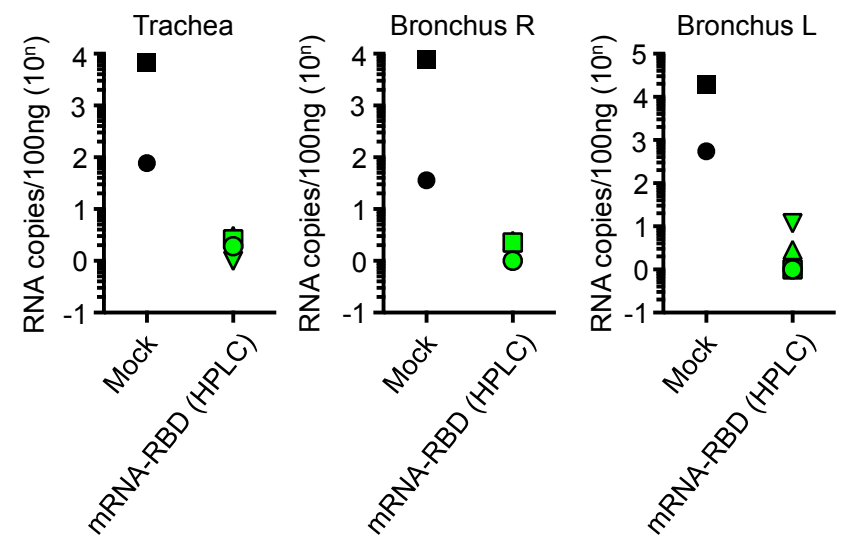
bioRxiv preprint doi: https://doi.org/10.1101/2021.03.04.433852; this version posted March 4, 2021. The copyright holder for this preprint (which was not certified by peer review) is the author/funder, who has granted bioRxiv a license to display the preprint in perpetuity. It is made available under aCC-BY-NC-ND 4.0 International license.

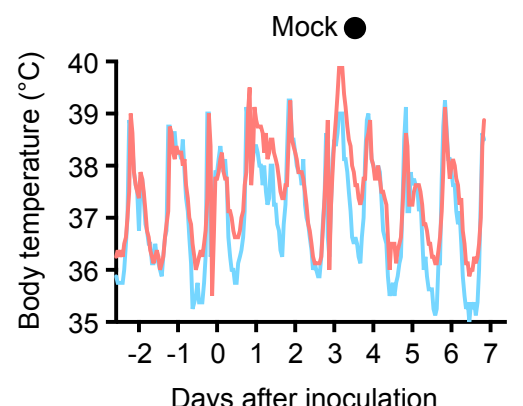

Days after inoculation

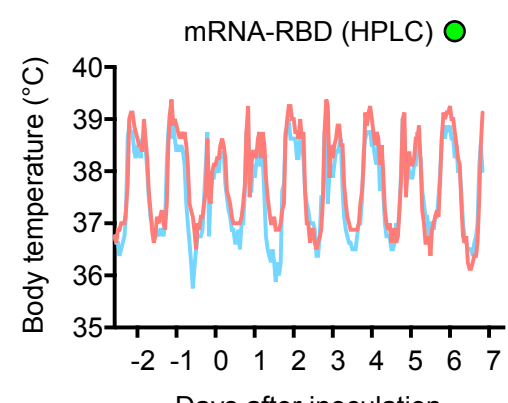

Days after inoculation

mRNA-RBD (HPLC) $\Delta$

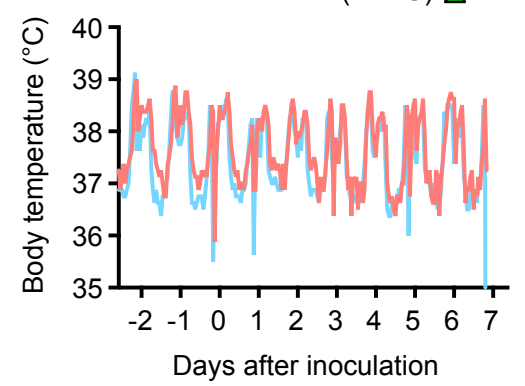

Mock

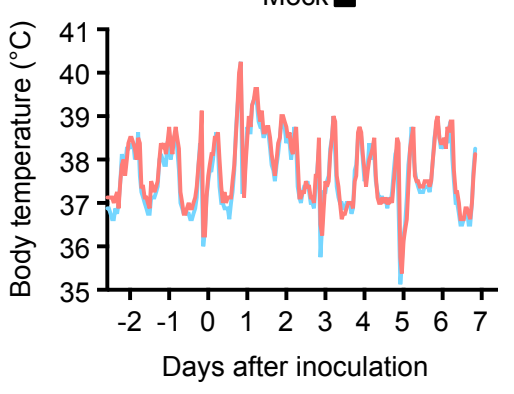

mRNA-RBD (HPLC) $\square$

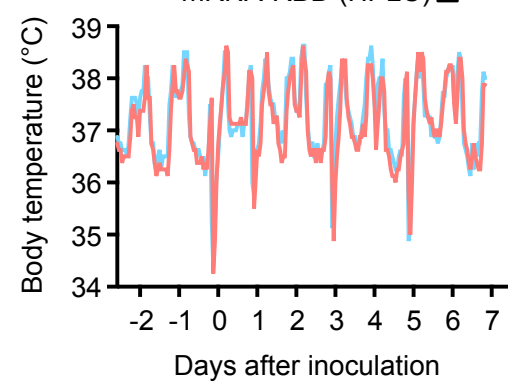

mRNA-RBD (HPLC) $\nabla$

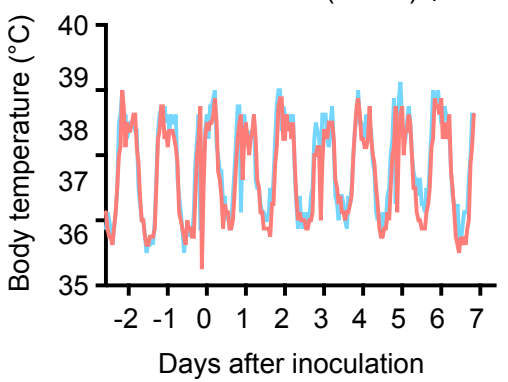


bioRxiv preprint doi: https://doi.org/10.1101/2021.03.04.433852; this version posted March 4, 2021. The copyright holder for this preprint (which was not certified by peer review) is the author/funder, who has granted bioRxiv a license to display the preprint in perpetuity. It is made available under aCC-BY-NC-ND 4.0 International license.

Mock

day0

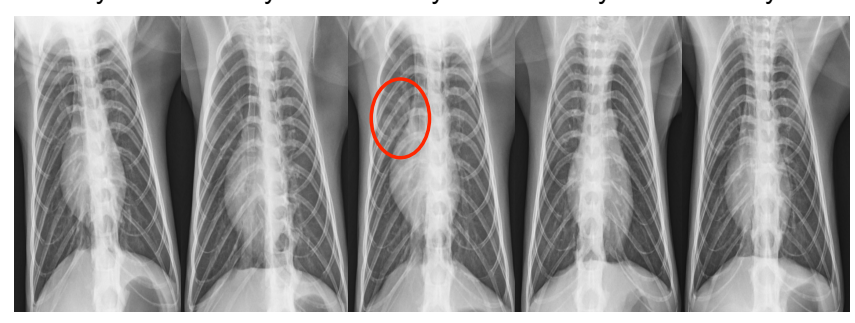

\section{Mock}

day0

day1

day3

day5

day7

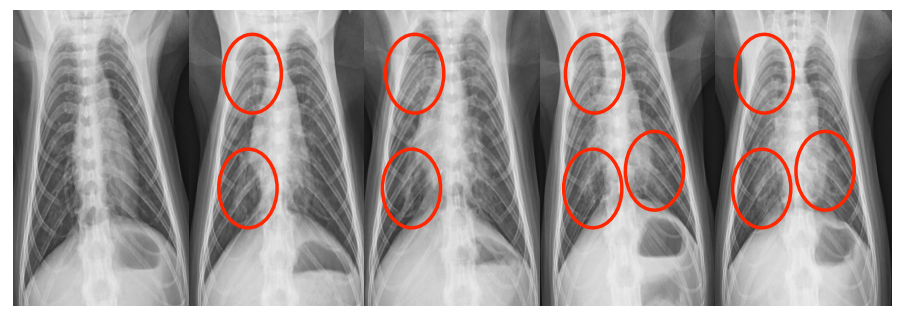

mRNA-RBD (HPLC) O
day0
day 1

\begin{abstract}
day3
\end{abstract}
day5
day7

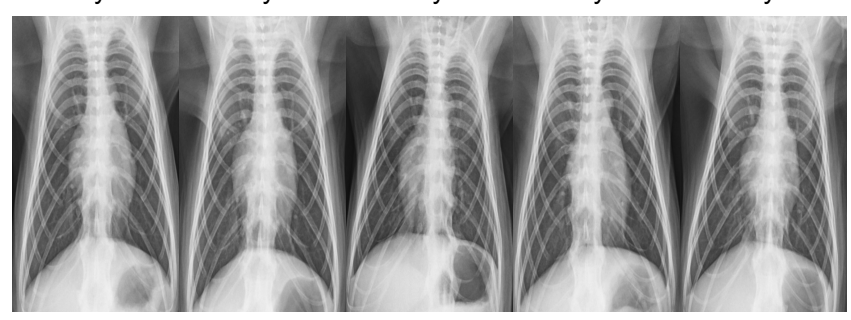

mRNA-RBD (HPLC) $\square$

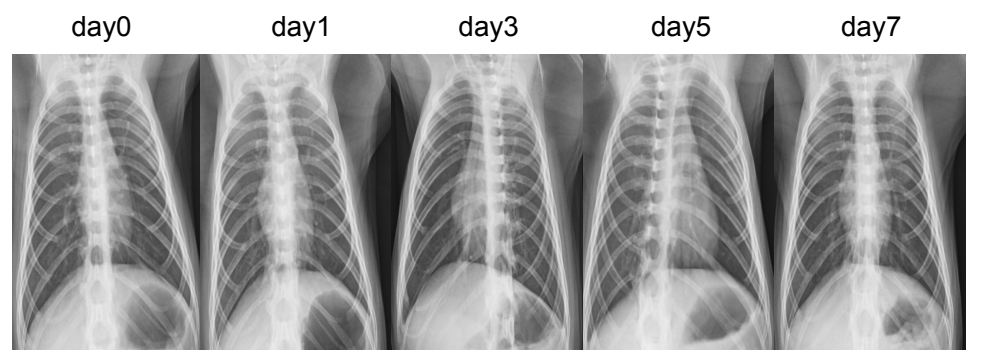

mRNA-RBD (HPLC) $\triangle$

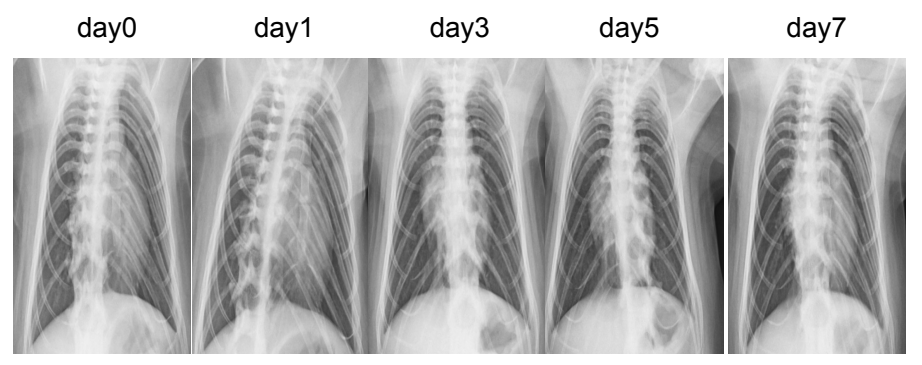

mRNA-RBD (HPLC) $\nabla$

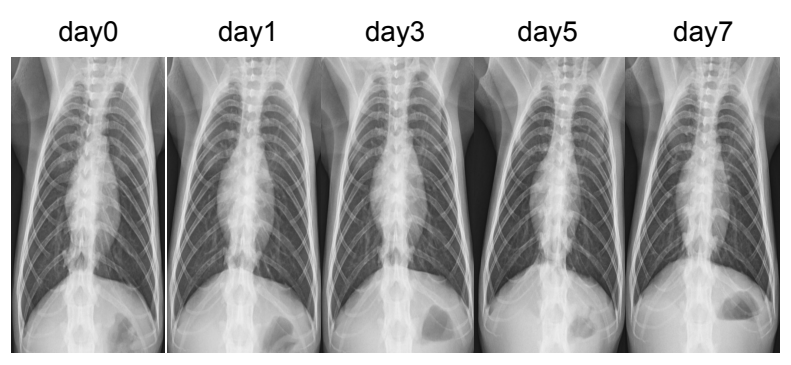

